\title{
Linking uncertainty in simulated Arctic ozone loss to uncertainties in modelled tropical stratospheric water vapour
}

\author{
Laura Thölix $^{1}$, Alexey Karpechko ${ }^{2}$, Leif Backman ${ }^{1}$, and Rigel Kivi ${ }^{3}$ \\ ${ }^{1}$ Climate System Research, Finnish Meteorological Institute, Helsinki, Finland \\ ${ }^{2}$ Meteorological Research, Finnish Meteorological Institute, Helsinki, Finland \\ ${ }^{3}$ Earth Observation Research, Finnish Meteorological Institute, Sodankylä, Finland
}

Correspondence: Laura Thölix (laura.tholix@fmi.fi)

Received: 23 March 2018 - Discussion started: 24 April 2018

Revised: 28 September 2018 - Accepted: 4 October 2018 - Published: 19 October 2018

\begin{abstract}
Stratospheric water vapour influences the chemical ozone loss in the polar stratosphere via control of the polar stratospheric cloud formation. The amount of water vapour entering the stratosphere through the tropical tropopause differs substantially between simulations from chemistry-climate models (CCMs). This is because the present-day models, e.g. CCMs, have difficulties in capturing the whole complexity of processes that control the water transport across the tropopause. As a result there are large differences in the stratospheric water vapour between the models.

In this study we investigate the sensitivity of simulated Arctic ozone loss to the simulated amount of water vapour that enters the stratosphere through the tropical tropopause. We used a chemical transport model, FinROSE-CTM, forced by ERA-Interim meteorology. The water vapour concentration in the tropical tropopause was varied between 0.5 and 1.6 times the concentration in ERA-Interim, which is similar to the range seen in chemistry-climate models. The water vapour changes in the tropical tropopause led to about $1.5 \mathrm{ppmv}$ less and $2 \mathrm{ppmv}$ more water vapour in the Arctic polar vortex compared to the ERA-Interim, respectively. The change induced in the water vapour concentration in the tropical tropopause region was seen as a nearly one-to-one change in the Arctic polar vortex.

We found that the impact of water vapour changes on ozone loss in the Arctic polar vortex depends on the meteorological conditions. The strongest effect was in intermediately cold stratospheric winters, such as the winter of 2013/2014, when added water vapour resulted in $2 \%-7 \%$ more ozone loss due to the additional formation of polar stratospheric
\end{abstract}

clouds (PSCs) and associated chlorine activation on their surface, leading to ozone loss. The effect was less pronounced in cold winters such as the 2010/2011 winter because cold conditions persisted long enough for a nearly complete chlorine activation, even in simulations with prescribed stratospheric water vapour amount corresponding to the observed values. In this case addition of water vapour to the stratosphere led to increased areas of ICE PSCs but it did not increase the chlorine activation and ozone destruction significantly. In the warm winter of 2012/2013 the impact of water vapour concentration on ozone loss was small because the ozone loss was mainly $\mathrm{NO}_{x}$-induced. The results show that the simulated water vapour concentration in the tropical tropopause has a significant impact on the Arctic ozone loss and therefore needs to be well simulated in order to improve future projections of the recovery of the ozone layer.

\section{Introduction}

Water vapour in the stratosphere is a minor constituent with typical mixing ratios of 3-6 ppmv (e.g. Randel et al., 2004). It plays, however, an important role in radiative and chemical processes, especially in the upper troposphere-lower stratosphere (UTLS), where changes in the water vapour concentration result in significant changes in radiative forcing of the troposphere (Riese et al., 2012). Dessler et al. (2013) suggested that, as a result of global warming, tropopause temperature will increase, leading to an increase in stratospheric water vapour (SWV). Since water vapour is a greenhouse gas, future increases in SWV will provide a positive feed- 
back further warming the troposphere below. However, tropospheric warming may also lead to a significant cooling near the tropopause in connection with deep convection (Kim et al., 2018), so that the link between warming climate and tropopause temperature is not straightforward. Photodissociation of water vapour is an important source of odd hydrogen $\mathrm{HO}_{x}\left(\mathrm{H}+\mathrm{OH}+\mathrm{HO}_{2}\right)$. Catalytic cycles involving $\mathrm{HO}_{x}$ contribute to chemical ozone loss in the stratosphere (Dvortsov and Solomon, 2001). Water vapour contributes to the formation of stratospheric aerosols including polar stratospheric clouds (PSCs), i.e. liquid and solid particles in combination with $\mathrm{H}_{2} \mathrm{SO}_{4}$ and $\mathrm{HNO}_{3}$, or ice particles (e.g. Hamill et al., 1997).

Heterogeneous reactions in or on PSC particles can lead to massive ozone depletion inside the polar vortices when atmospheric concentration of halogens is sufficiently high (Solomon et al., 1986; Wohltmann et al., 2013). Since the formation of PSCs requires very low temperatures (below about $195 \mathrm{~K}$ ) that are rarely reached in the Arctic, significant polar ozone depletion takes place there only occasionally (Rex et al., 2006; Manney et al., 2011; Müller et al., 2008; Chipperfield et al., 2015), while it has been a yearly phenomenon in the Antarctic since about the mid-1980s (e.g. Dameris et al., 2014). The stratospheric abundance of chlorine will remain elevated for decades, and polar ozone losses will therefore also be seen in the future. Equivalent effective stratospheric chlorine (EESC) is a proxy that is frequently used to describe the combined effect of chlorine and bromine on stratospheric ozone. The level of EESC in 1980 is commonly taken as a level that needs to be reached to achieve a recovery of stratospheric ozone. According to a recent study by Engel et al. (2018), the EESC would return to the 1980 level in 2077 for a mean age of 5.5 years, which is representative of polar winter conditions. Several studies have discussed Antarctic ozone depletion and its recovery (see, e.g. Eyring et al., 2010; Dameris et al., 2014; Solomon et al., 2016; Chipperfield et al., 2017; Kuttippurath and Nair, 2017; Strahan and Douglass, 2018). Kuttippurath and Nair (2017) showed, based on ozone balloon soundings and total ozone data from satellite instruments, that Antarctic ozone has begun to recover. Based on data from the Aura Microwave Limb Sounder (MLS) of $\mathrm{HCl}$ and ozone, Strahan and Douglass (2018) could show a decline in lower stratosphere chlorine and a corresponding decline in ozone depletion for the period 2013-2016 compared to the period 2004-2007. However, a recovery of ozone to 1980 ozone levels is projected not to occur until around 2025-2043 in the Arctic and 20552066 in the Antarctic (Dhomse et al., 2018). Both colder air and increased SWV can increase the formation of PSCs, which could release more active chlorine and cause severe ozone depletion, although future chlorine loadings will be smaller. All these suggest that SWV is a critical factor affecting ozone chemistry.

The majority of the previous studies addressing impacts of SWV on Arctic ozone depletion considered the effects of observed and projected increases in SWV concentrations (Eyring et al., 2007; Kirk-Davidoff et al., 1999; Dvortsov and Solomon, 2001; MacKenzie and Harwood, 2004; Stenke and Grewe, 2005; Feck et al., 2008; Vogel et al., 2011). For example Vogel et al. (2011) used a chemistry-transport model (CTM) and studied the effect of increased SWV on Arctic ozone loss for meteorological conditions from the cold Arctic winter of 2004/2005. They found that increasing SWV by 0.58 ppmv, which is a typical amount simulated by chemistry-climate models (CCMs) by the mid-21st century (Eyring et al., 2007), would lead to an additional 6 DU of ozone loss under cold winter conditions. Sinnhuber et al. (2011) used a CTM driven by meteorological conditions for the cold Arctic winter of 2010/2011 and assumed a uniform increase of SWV of $1 \mathrm{ppmv}$. For such conditions they reported a $25 \mathrm{DU}$ increase in ozone loss, i.e. about $20 \%$ of their simulated total ozone loss for that winter.

Smalley et al. (2017) studied future trends in the tropical lower stratospheric water vapour and provided a regression model for analysing the factors driving the trends and variability in the 21 st century. They found that warming of the troposphere causes a long-term increasing trend in the water vapour entering the stratosphere, which can be partially offset by an increase of the Brewer-Dobson circulation with accompanied cooling of the tropical tropopause. MacKenzie and Harwood (2004) studied the effect of increasing SWV due to future increase in tropospheric methane on ozone. They simulated the year 2060 under the Intergovernmental Panel on Climate Change Special Report on Emission Scenarios (SRES) B2 scenario, in which $\mathrm{CH}_{4}$ lies approximately midway between the extremes of the SRES scenarios. They found an increase in the occurrence of PSCs, with about $20 \%$ to $25 \%$ due to increase in the water vapour. The rest is from radiative cooling of the middle atmosphere due to changes in the concentration of several trace gases. In the simulations by MacKenzie and Harwood (2004) the increased SWV due to projected methane increases caused a $15 \%$ (about $0.5 \mathrm{ppmv}$ at $465 \mathrm{~K}$ level) deeper Arctic ozone loss in 2060 . However, cooling of the stratosphere could at least partially offset the effect of the increased PSCs by slowing down the secondorder reactions in ozone loss cycles (Rosenfield et al., 2002; Revell et al., 2012). This effect is mainly seen in $\mathrm{NO}_{x}$ - and $\mathrm{HO}_{x}$-induced loss outside the polar vortex, while the effect on PSCs from temperature is seen within the vortex.

Revell et al. (2016) also studied the effect of future methane changes on SWV under different Representative Concentration Pathway (RCP) scenarios. The contribution of methane to the SWV was found to be highly dependent on the projected methane concentration, altitude and latitude. Under RCP 6.0, between 1960 and 2100 the SWV was projected to increase by approximately 1 ppmv throughout most of the stratosphere, excluding the Antarctic lower stratosphere. The largest increase was seen following the RCP 8.5, with $60 \%$ additional water vapour in the extratropical upper stratosphere, and ca. $35 \%$ in the Arctic lower stratosphere. 
The largest contribution from methane to the SWV change was about $50 \%$ under RCP 8.5, which assumes a rather extreme methane increase scenario, and the smallest was about $4 \%$ under RCP 2.6.

Recently Sagi et al. (2017) studied Arctic ozone losses between the years 2002 and 2013 using data assimilation of Odin sub-millimetre radiometer (SMR) observations. They found that the largest ozone losses were caused either by halogens or by the $\mathrm{NO}_{x}$ family, and the dominating process for ozone destruction is determined mostly by the temperatures inside the polar vortex. The very stable and cold polar vortex in the Arctic winter of 2010/2011 led to remarkable halogen-driven ozone loss, with 2.1 ppmv ozone destroyed at the $450 \mathrm{~K}$ level. In the winter of 2012/2013 the polar vortex was more unstable and a vortex split occurred in early January due to a sudden stratospheric warming (SSW), and $\mathrm{NO}_{x}$-rich air from the mesosphere descended to the upper stratosphere and led to ozone loss there. Thus the effect on Arctic ozone depletion from changes in SWV depends on the meteorological conditions and the dynamical stability in a given winter.

The main source of SWV is the upward transport from the troposphere through the tropical tropopause in the upwelling branch of the Brewer-Dobson circulation. The concentration of SWV is controlled by the coldest temperature met by the ascending air parcels (i.e. cold point temperature). Gettleman et al. (2010) analysed 16 state-of-the-art CCMs and demonstrated large discrepancies between simulated SWV levels in these models, which were closely related to the simulated cold point temperatures. The "entry" value of SWV in these models ranged between 2 and 6 ppmv, compared to the observed value of 3-4 ppmv. These inter-model differences by far exceed the magnitude of the projected water vapour increases in the 21 century used so far in the studies of ozone loss sensitivities to SWV. One may wonder what the implications of these discrepancies for stratospheric ozone losses simulated by CCMs are. This question is difficult to address by analysing CCM outputs because there are other differences between the models which affect simulated ozone losses, such as differences in simulated transport. Therefore a more controlled experiment is needed in order to assess the impact of these SWV changes on ozone loss.

In this study we address the question of what the implications of the differences in simulated tropical stratospheric water vapour between chemistry-climate models are for the simulated Arctic ozone loss. Similar to Vogel et al. (2011) and Sinnhuber et al. (2011) we address this question by performing CTM simulations using different SWV concentrations. The principal differences in our methodology from the previous studies are (1) the boundary conditions of perturbed water vapour experiments resulting in a different spatial pattern of SWV anomalies and (2) the magnitude of SWV perturbation, which is larger than in the Vogel et al. (2011) and Sinnhuber et al. (2011) studies, but in the range of Revell et al. (2016) and MacKenzie and Harwood (2004). We also analysed seven different winters, whose dynamical circumstances such as the evolution of the temperature and polar vortex were different (see Sect. 3 for more details).

\section{Modelling and data}

A global offline chemistry-transport model for the middleatmosphere, FinROSE-CTM, was used for simulating the effect of the SWV on Arctic ozone depletion. The FinROSECTM is described in detail in Damski et al. (2007b). In this study, the model has a horizontal resolution of $3^{\circ} \times 6^{\circ}$ (latitude $\times$ longitude). It has 40 hybrid sigma levels up to $0.1 \mathrm{hPa}$ (about $65 \mathrm{~km}$ ). The temperature, winds and surface pressure are from the European Centre for Medium-range Weather Forecasts (ECMWF) ERA-Interim reanalyses (Dee et al., 2011).

The model transport is computed using a flux-form semiLagrangian transport code (Lin and Rood, 1996). The chemistry scheme of the model comprises 36 species and includes about 150 reactions. In addition to gas-phase chemistry, the model includes a PSC scheme with liquid binary aerosols (LBA), supercooled ternary solution of sulfuric acid, nitric acid and water (STS, type Ib), solid nitric acid trihydrate (NAT, type Ia) and ice (ICE, type II) PSCs. The heterogeneous chemistry includes 30 reactions altogether and is based on the calculation of the composition and volume of sulfate aerosols and PSCs, as well as the partitioning of species between the gas phase and the condensed phase. The number density profile is prescribed for each PSC type (Damski et al., 2007b) and the sulfuric acid distribution is based on 2D model data (Bekki and Pyle, 1992). Absorption cross sections and rate coefficients follow the recommendations by Sander et al. (2011), and for some heterogeneous reactions the recommendations by Atkinson et al. (2007) are used; see details in Damski et al. (2007b). The reaction rates on NAT and ICE PSCs are not directly affected by the water vapour concentration except through the available surface area; i.e. the uptake coefficients are constant. Water vapour and $\mathrm{HNO}_{3}$ condenses onto the binary aerosol and STS droplets, making them more dilute, which increases the uptake coefficients of some reactions, i.e the hydrolysis reactions of $\mathrm{ClONO}_{2}$, $\mathrm{BrONO}_{2}$ and $\mathrm{N}_{2} \mathrm{O}_{5}$, as well as the reaction of $\mathrm{HCl}$ between $\mathrm{ClONO}_{2}$ and $\mathrm{HOCl}$ (Sander et al., 2011). The sedimentation of PSC particles, which can lead to denitrification and dehydration, is calculated based on the settling velocity, which takes the PSC particle size into account.

Lookup tables of photodissociation coefficients were precalculated using the PHODIS model (Kylling et al., 1995). Within PHODIS the radiative transfer equation is solved by the discrete ordinate algorithm (Stamnes et al., 1988). This algorithm has been modified to account for the spherical shape of the atmosphere using the pseudospherical approximation (Dahlback et al., 1991). 
The tropospheric concentrations of the chemical species are prescribed via model boundary conditions. The boundary conditions of water vapour and ozone are taken from the ECMWF ERA-Interim reanalysis (Dee et al., 2011) except for the water vapour boundary conditions in the sensitivity experiments, which are described below. The concentration of tropospheric methane $\left(\mathrm{CH}_{4}\right)$ is from GLOBALVIEW data (https://www.esrl.noaa.gov/gmd/ccgg/globalview/; last access: 16 October 2018), nitrous oxide $\left(\mathrm{N}_{2} \mathrm{O}\right)$ concentration is from Agage data (Prinn et al., 2000), and halogens' concentrations in the troposphere (Cly and Bry) are from Montzka et al. (1999) updated data. The carbon dioxide $\left(\mathrm{CO}_{2}\right)$ concentration is based on global annual mean trend data (ftp://aftp.cmdl.noaa.gov/products/trends/co2; last access: 16 October 2018$)$. At the upper boundary $(0.1 \mathrm{hPa})$ climatological values of water vapour and ozone averaged over 2005-2013 from MLS data were used.

The FinROSE-CTM has previously been used to study the impact of meteorological conditions on water vapour trends (Thölix et al., 2016), ozone and $\mathrm{NO}_{x}$ chemistry in the mesosphere (Salmi et al., 2011), Arctic polar ozone loss (Karpechko et al., 2013) and the impact of the driver data on the model transport (Thölix et al., 2010). Long-term trends of Arctic and Antarctic ozone losses, past and future, have been investigated by using driving data from a chemistryclimate model (Damski et al., 2007a). The model results showed good agreement with satellite and ground-based observations. The FinROSE water vapour was compared to observations of water vapour profiles from the Microwave Limb Sounder (MLS) and frost point hygrometer soundings from Sodankylä (Thölix et al., 2016). The extent of ICE PSCs simulated by FinROSE was compared to Cloud-Aerosol Lidar and Infrared Path finder Satellite Observation (CALIPSO) data in Thölix et al. (2016). The total ozone distribution was compared to data from Total Ozone Mapping Spectrometer (TOMS) and the Ozone Monitoring Instrument (OMI) satellite instruments in Damski et al. (2007a), Thölix et al. (2010) and Karpechko et al. (2013). Salmi et al. (2011) compared the $\mathrm{NO}_{x}$ and ozone profiles in FinROSE to data from the Atmospheric Chemistry Experiment Fourier Transform Spectrometer (ACE-FTS) instrument.

For this study, three simulations covering the Arctic winters between 2009/2010 and 2015/2016 were performed. The simulations differed from each other by the prescribed water vapour concentration in the tropical tropopause region (stratosphere between $21^{\circ} \mathrm{S}$ and $21^{\circ} \mathrm{N}$, below $80 \mathrm{hPa}$ ), where it was prescribed as follows: (1) water vapour taken from ERA-Interim (Interim simulation), (2) increased water vapour (Max simulation) and (3) decreased water vapour (Min simulation). Specifically, the SWV lower boundary conditions for Min and Max simulations were obtained by multiplying values from ERA-Interim between the tropopause and $80 \mathrm{hPa}$, and between $21^{\circ} \mathrm{S}$ and $21^{\circ} \mathrm{N}$ by monthly coefficients ranging between 1.46 and 1.7 (Max) and between 0.5 and 0.63 (Min), so that they approximately correspond to the driest and wettest CCM, as determined by SWV values at the tropical tropopause, across models analysed by Gettleman et al. (2010). This construction allows us to isolate the influence of the tropical water vapour on stratospheric chemistry while keeping all other factors fixed, and thus to estimate the contribution of processes controlling tropical water vapour entry values to Arctic ozone loss. Eight simulated years before 2009 are considered as spin-up and were not analysed. Ozone was initialized with ERA-Interim ozone in every year, in the beginning of December. The water vapour concentration was not adjusted and allowed to evolve freely through the whole period of integrations. Ozone and water vapour observations from MLS (Lambert et al., 2007) were used to validate the reference simulation. MLS data are shown as 5-day averages because of the small amount of data covering the polar vortex in some cases.

\section{Results}

Model simulations were made for seven winters (20092016), but only four of them are discussed here. The four selected Arctic winters, 2010/2011, 2012/2013, 2013/2014 and 2015/2016 differ from each other with respect to the stratospheric temperatures and polar vortex strength. They provide examples of the different roles of SWV in ozone loss in mild (2012/2013), cold $(2010 / 2011,2015 / 2016)$ and intermediate (2013/2014) stratospheric winter conditions.

\subsection{Temperature and water vapour}

The boundary condition at the tropical tropopause for the reference simulation was evaluated by comparing simulated water vapour concentrations with observed ones from MLS. The top panels in Fig. 1 show daily mean water vapour at $80 \mathrm{hPa}$ averaged between $21^{\circ} \mathrm{S}$ and $21^{\circ} \mathrm{N}$ for the two representative years of 2013 and 2014. The temperature for the same region is shown in the lower panels. The cold point, where SWV boundary conditions were prescribed, is just below the $80 \mathrm{hPa}$ level. The temperature shows the typical annual cycle with minimum temperature in the Northern Hemisphere $(\mathrm{NH})$ winter and maximum temperature in the $\mathrm{NH}$ summer. The temperature in the tropical tropopause layer (TTL) controls how much water vapour enters the stratosphere by freeze-drying the upwelling air (e.g. Fueglistaler et al., 2005). As a result the maximum water vapour concentration occurs in the $\mathrm{NH}$ autumn and minimum in the early $\mathrm{NH}$ spring. The effect of interannual variability and shorter term variations in the temperature on stratospheric water vapour can also be seen; e.g. the low temperature in early 2013 results in $0.5-1$ ppmv less water vapour than during the same time in 2014.

The Interim simulation produces water vapour concentrations comparable to the amount seen by MLS (Fig. 1), which shows that the boundary condition is reasonable. However, 


\section{$21^{\circ} \mathrm{S}-21^{\circ} \mathrm{N}, 80 \mathrm{hPa}$}
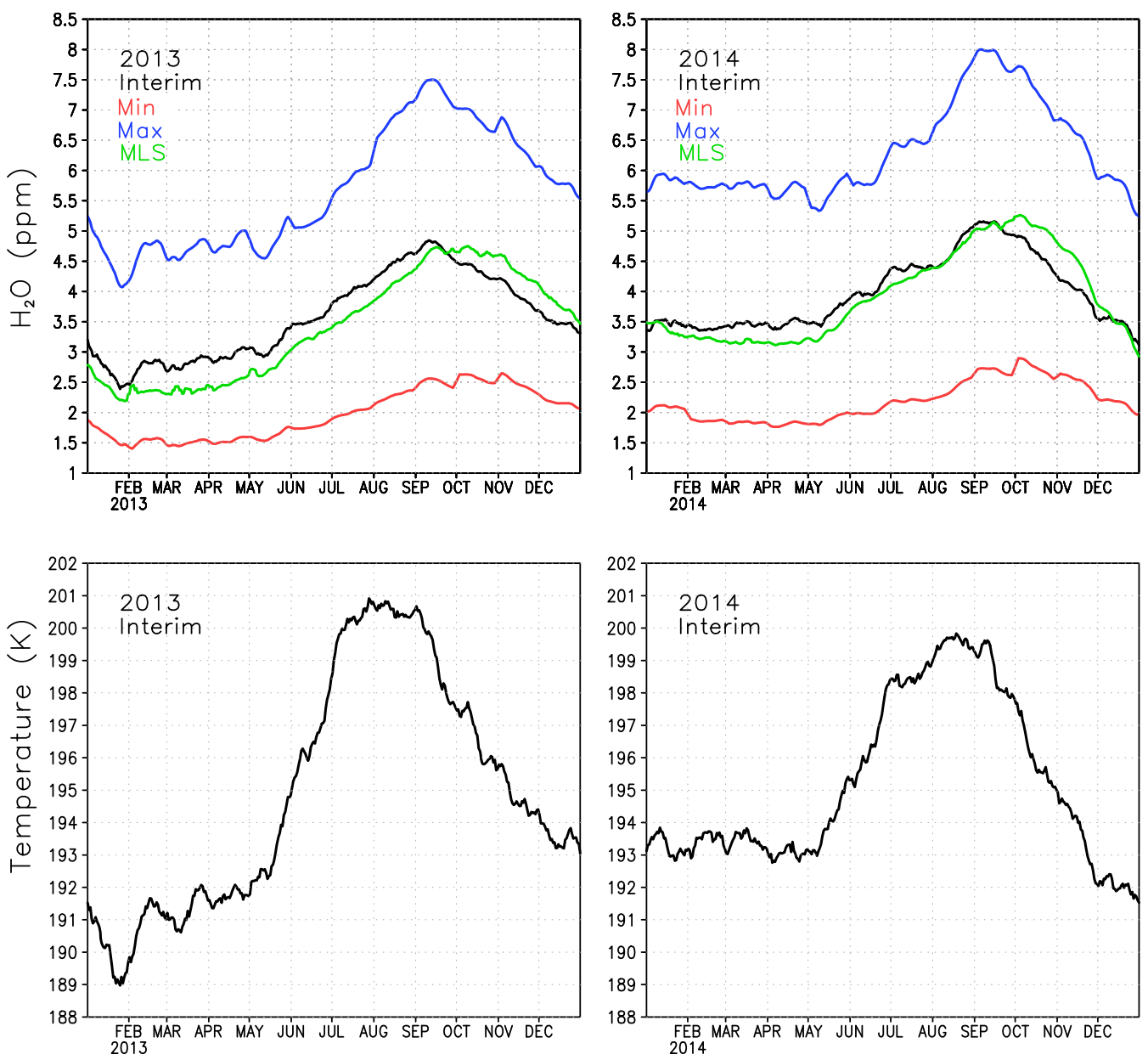

Figure 1. Water vapour and temperature around the tropical tropopause between $21^{\circ} \mathrm{S}$ and $21^{\circ} \mathrm{N}$ at level $80 \mathrm{hPa}$ in 2013 and 2014 . The green line denotes the Interim simulation, blue denotes the Max simulation, red denotes the Min simulation and black denotes the MLS.

Interim variability is ahead that of MLS by 3-4 weeks. The reason for the time lag between Interim and MLS is not clear, although it could at least partly be associated with too fast a Brewer-Dobson circulation in ERA-Interim, which is responsible for the upward transport of the water vapour anomalies in the tropics (Schoeberl et al., 2012). The Max simulation has $2-3$ ppmv more water vapour in the tropics than the Interim simulation, while the Min simulation is about $1.5 \mathrm{ppmv}$ drier than the Interim simulation. These differences correspond to the ratio between Max and Interim of approximately $1.55-1.6$ and about $0.55-0.6$ between Min and Interim; i.e. they are consistent with the prescribed boundary conditions.

We next describe the meteorological condition in the Arctic stratosphere during the analysed winters. Figure 2 shows the daily average temperature in the Arctic polar vortex in the winters of 2010/2011, 2012/2013, 2013/2014 and
2015/2016. The polar vortex was identified using the modified potential vorticity (Lait, 1994), with the $475 \mathrm{~K}$ potential temperature as a reference level. Here the polar vortex is defined as the area enclosed by the $36 \mathrm{PVU}$ isoline separately for every model level. The $36 \mathrm{PVU}$ contour approximately corresponds to the region of the maximum PV gradient, i.e the polar vortex edge (Rex et al., 1999; Streibel et al., 2006). The winter of 2010/2011 represents a cold winter, with vortex average temperatures below $200 \mathrm{~K}$ and minimum temperatures below $195 \mathrm{~K}$, sufficient for the formation of NAT/STS PSCs, throughout most of the winter, from December to the beginning of April, with only a brief interruption by a warming in early January. Minimum temperatures in the vortex were record cold and below $190 \mathrm{~K}$, even at the end of March (Manney et al., 2011). The winter of 2012/2013 is an example of a warm Arctic stratospheric winter. Vortex average temperatures below $195 \mathrm{~K}$ were seen for only 

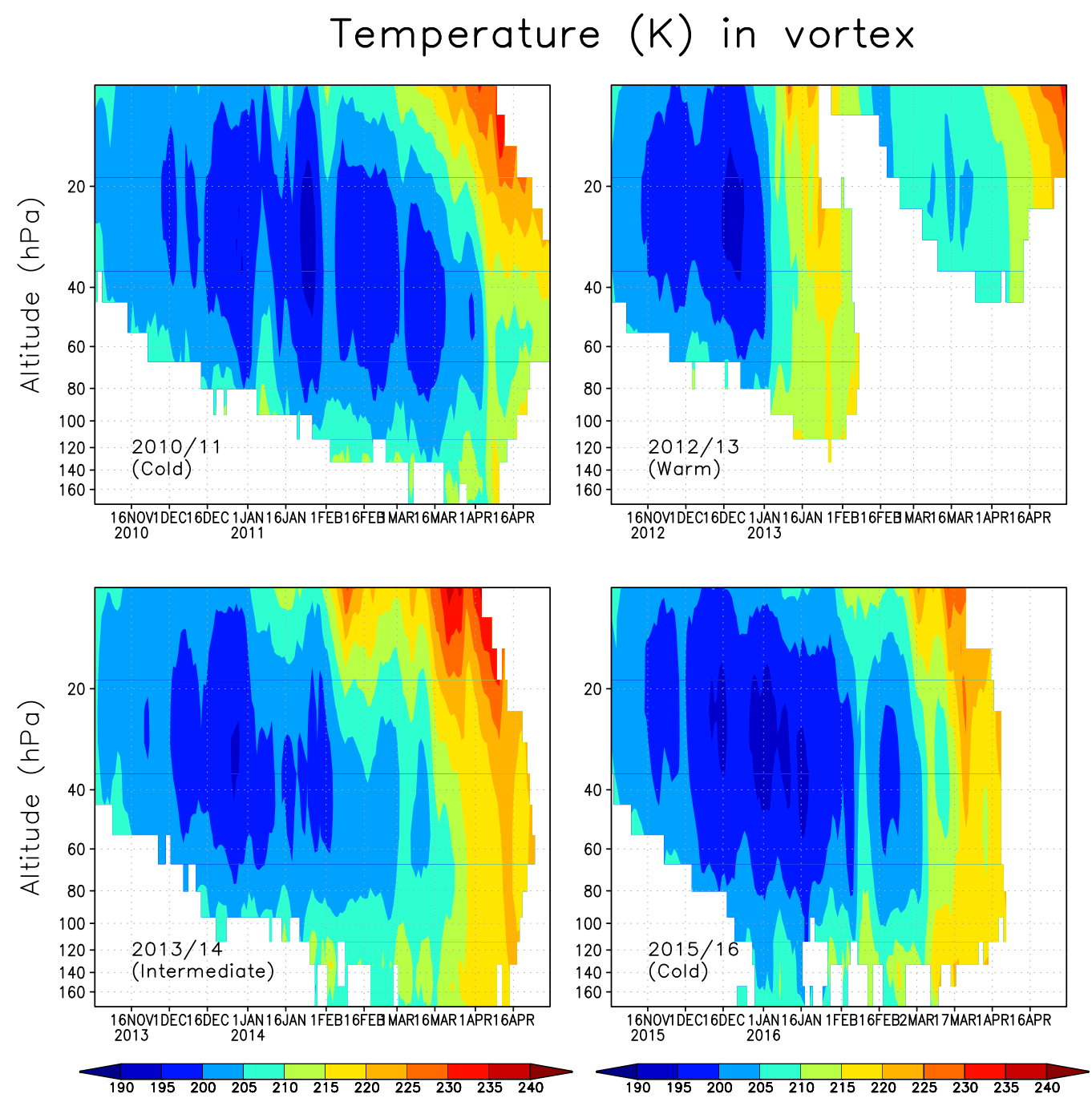

Figure 2. Vortex average temperature within the Arctic polar vortex between altitudes 170 and $10 \mathrm{hPa}$.

a few days in December in the ERA-Interim data, and the minimum temperature was below $195 \mathrm{~K}$ until mid-January. A SSW occurred in early January, followed by a weakening and a break-up of the polar vortex in the lower stratosphere already in February. The winter of 2013/2014 was intermediate, with average temperatures inside the polar vortex being close to the long-term climatological mean through most of the winter, until late March when a final SSW occurred. There were only a few days in late December when the average temperature was below $195 \mathrm{~K}$. The winter of 2015/2016 was as cold, or even colder, as the 2010/2011 winter during December-February with minimum vortex average temperatures below $195 \mathrm{~K}$. However, a minor SSW occurred in early February and the final warming came in early March, ending the cold period and reducing ozone depletion potential much earlier than in the 2010/2011 winter.
Figure 3 shows the 5-day running mean concentration of water vapour at $55 \mathrm{hPa}$ averaged over the Arctic polar vortex for winters 2010/2011, 2012/2013, 2013/2014 and 2015/2016. The gaps in the 2012/2013 MLS curve are due to an undefined vortex (or too small a vortex with only few observations) after the SSW. The water vapour concentration in the Interim simulation is comparable to the MLS data. However, the variability in water vapour is smaller in FinROSE than in the MLS data. Typically, there is a stronger increase in water vapour towards spring in the MLS observations compared to the FinROSE simulations. This is most evident in the winter of 2013/2014 when MLS concentrations increased by more than 1 ppmv between November and April while the simulated increase was only $0.3 \mathrm{ppmv}$. Although an increase by spring is expected due to downward transport of air with higher SWV concentration by the Brewer-Dobson circulation, the increase seen in MLS observations in 2014 is 


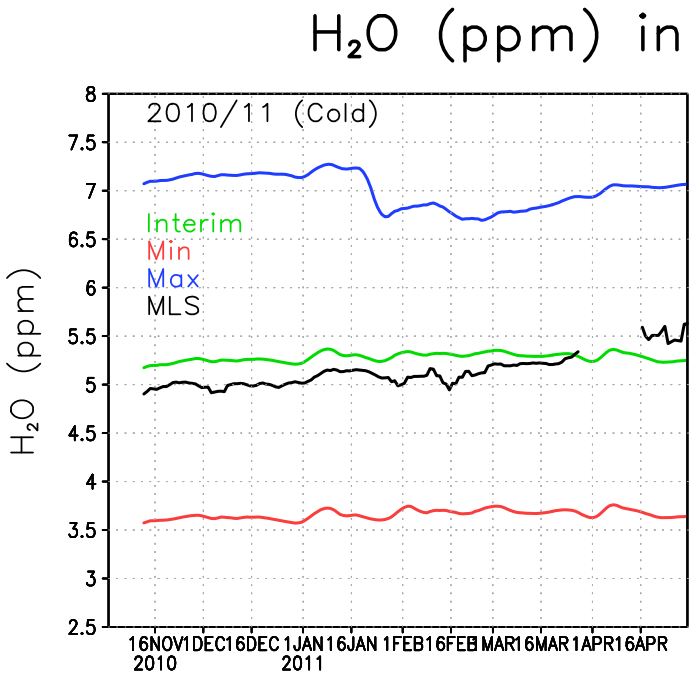

vortex, $55 \mathrm{hPa}$
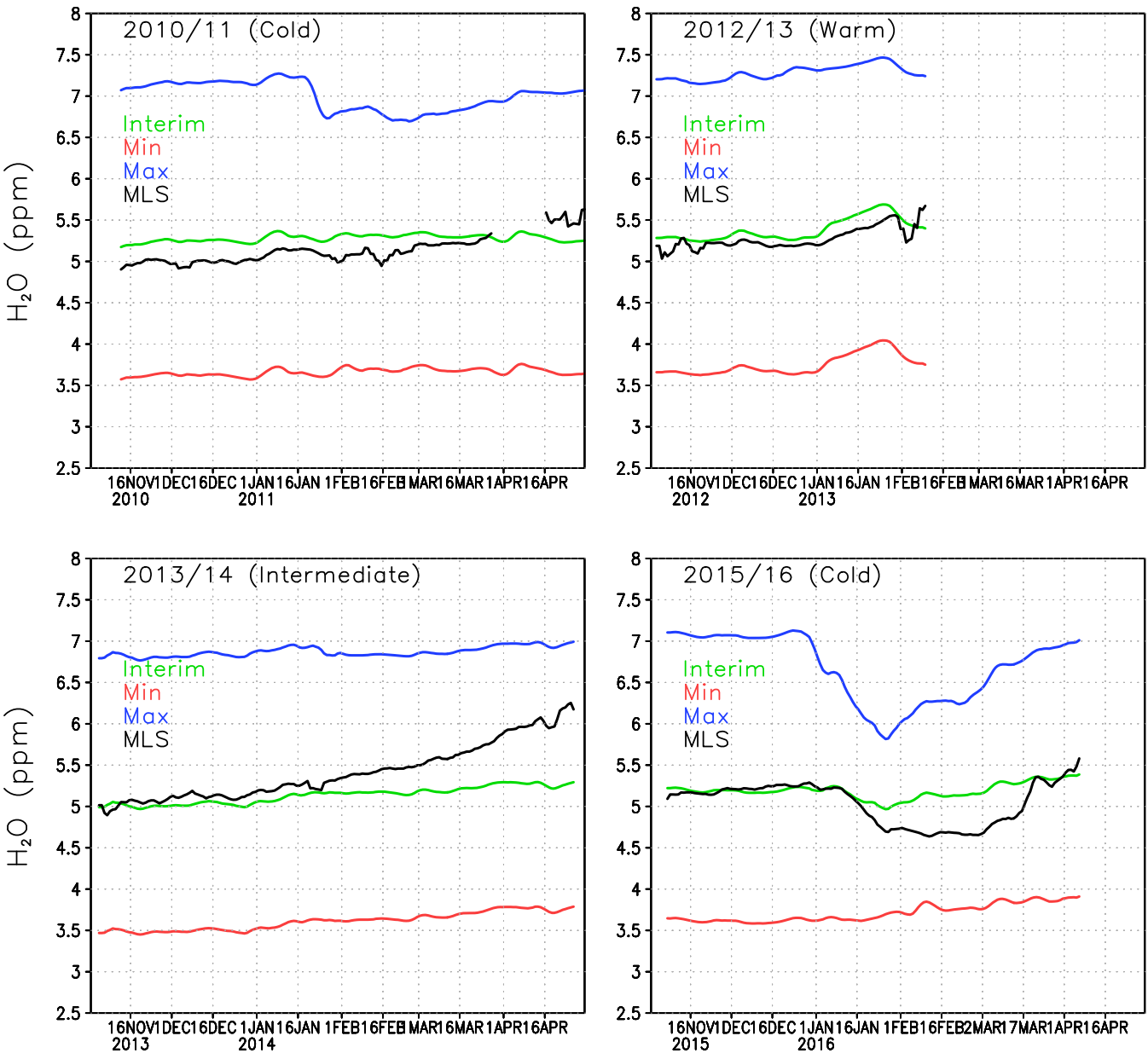

Figure 3. Water vapour concentration (ppmv) at $55 \mathrm{hPa}$ within the Arctic polar vortex. The green line denotes the Interim simulation, blue denotes the Max simulation, red denotes the Min simulation and black denotes the MLS.

unusual. For example the observed increase in January 2013 after the SSW associated with downward transport of waterrich air from above was about $0.3 \mathrm{ppmv}$ and that increase was reasonably well reproduced by FinROSE. Note that the MLS observations within the polar vortex are sparse, which adds some noise to the MLS vortex average. Also note that FinROSE vortex mean values are calculated using all data points inside the vortex even if MLS data are not available for each point. This approach increases the robustness of model estimates but at the same time complicates direct comparison with MLS. Interestingly, when looking at the $60-90^{\circ} \mathrm{N}$ average, which also includes air from outside the polar vortex, there is no similar spring increase in MLS data as can be seen in Fig. 3, and the agreement between FinROSE and MLS improves (not shown). In all winters, the Max simulation has about 2 ppmv more water vapour in the Arctic polar vortex than the Interim simulation, and the Min simulation is about $1.5 \mathrm{ppmv}$ drier than the Interim simulation. This indicates that the simulated differences in the polar vortex water vapour are about the same as the differences in the boundary conditions for the tropical tropopause (Fig. 1), despite the average increase in SSW between the TTL and the polar vortex of about $1.5 \mathrm{ppmv}$ in each run.

There are also several SWV decreases seen in Fig. 3, which are due to the formation of ICE PSCs and possibly also to dehydration due to sedimentation of ICE particles. The most pronounced one is in the winter of 2015/2016 when, during a very cold period (Fig. 2), the observed concentrations decreased from 5.2 to $4.7 \mathrm{ppmv}$ and remained low until late February. A relatively small decrease of only about $0.2 \mathrm{ppmv}$ was simulated in the Interim run. This decrease corresponds to the formation of ICE PSCs in the model (see Sect. 3.2 for discussion of PSC results), and therefore at least a part of the decrease could be explained by sedimentation. 


\section{ICE PSC area $\left(1 E 6 \mathrm{~km}^{2}\right), 55 \mathrm{hPa}$}
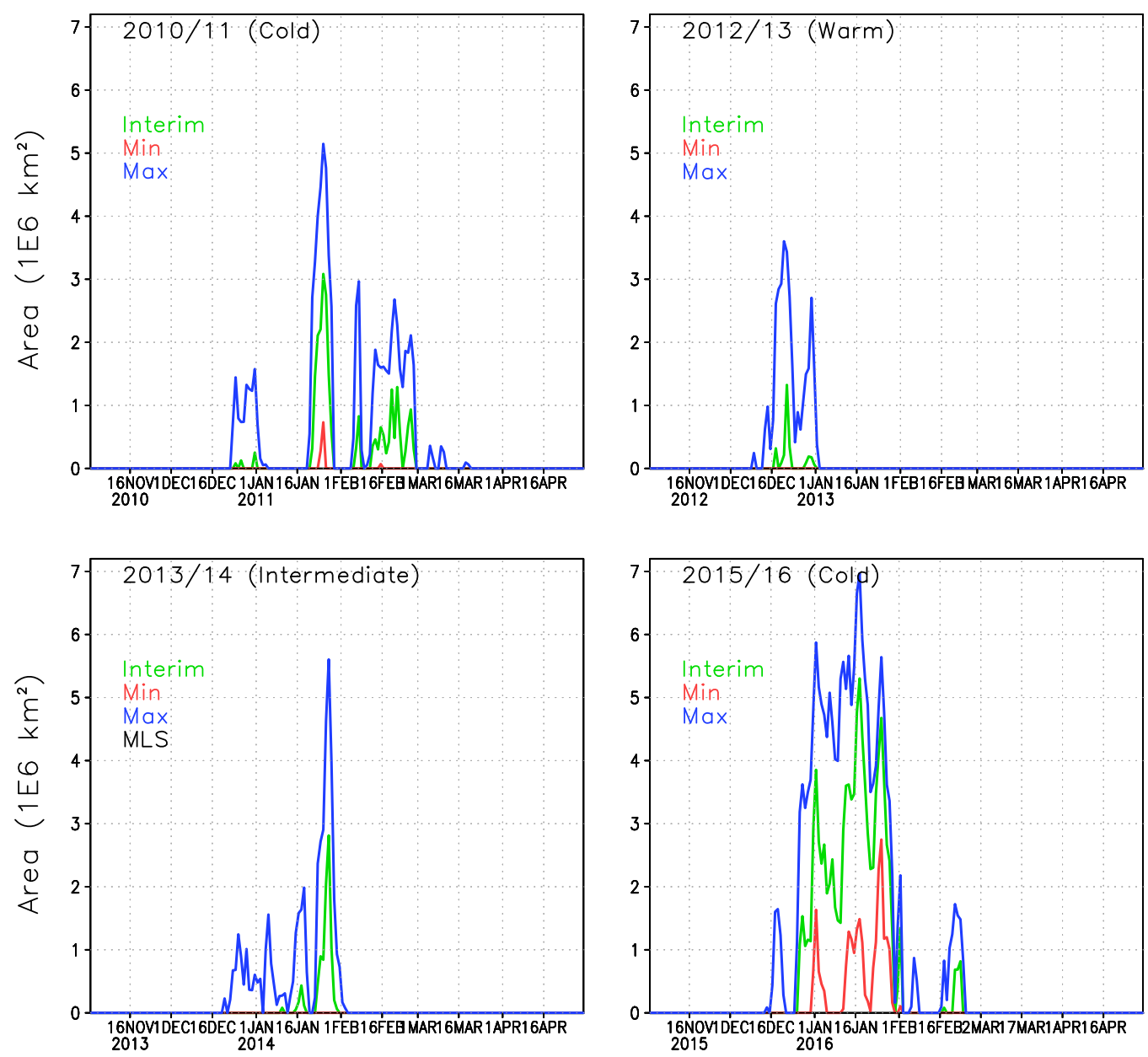

Figure 4. The areas of ICE PSCs $\left(10^{6} \mathrm{~km}^{2}\right)$ within the Arctic polar vortex in the FinROSE simulations at $55 \mathrm{hPa}$. The green line denotes the Interim simulation, blue denotes the Max simulation and red denotes the Min simulation.

A much larger decrease of about 1 ppmv was seen in the Max simulation starting from late December, which is consistent with a larger number of ICE PSCs simulated in this run. Another, much smaller, decrease of about 0.2 ppmv can be seen in the MLS observations during mid-January 2011 corresponding to a cold period. The decrease is almost undistinguishable in the Interim simulation, but is pronounced in the Max simulation, which is a result of a larger number of ICE PSCs.

\subsection{Polar stratospheric clouds}

Figures 4 and 5 show PSC type 2 (ICE) and PSC type 1a (STS) and b (NAT) areas at $55 \mathrm{hPa}$ (about $20 \mathrm{~km}$ ) in the Arctic polar vortex for winters 2010/2011, 2012/2013, 2013/2014 and 2015/2016. The area was calculated by summing the areas of model grid boxes containing PSCs. There is no formation temperature for STS droplets, but they are formed gradually as water, and $\mathrm{HNO}_{3}$ dissolves into binary aerosols with decreasing temperature. Here we have defined STS based on how much $\mathrm{HNO}_{3}$ has dissolved into the liquid phase; we set the limit at 0.6 pptv liquid $\mathrm{HNO}_{3}$ for any given grid point. The limit approximately corresponds to a formation threshold temperature of $202 \mathrm{~K}$ for STS.

In the winter of 2010/2011 the polar vortex was stable and cold, but not extremely cold. The ICE PSC area (Fig. 4) in the Interim simulation was mostly moderate except for a period in late January with cold temperatures and large ICE PSC areas. The ICE PSCs lasted longer in the spring than in other winters. It is unusual that ICE PSCs occur after January, but in 2011 ICE PSCs were seen through February, even in the Interim simulation. In the Max simulation the ICE PSCs lasted until mid-March. CALIPSO (Pitts et al., 2007, 2018; Spang et al., 2018) also observed PSCs in the 2010/2011 winter. The observed ICE PSC areas are comparable to the Fin- 


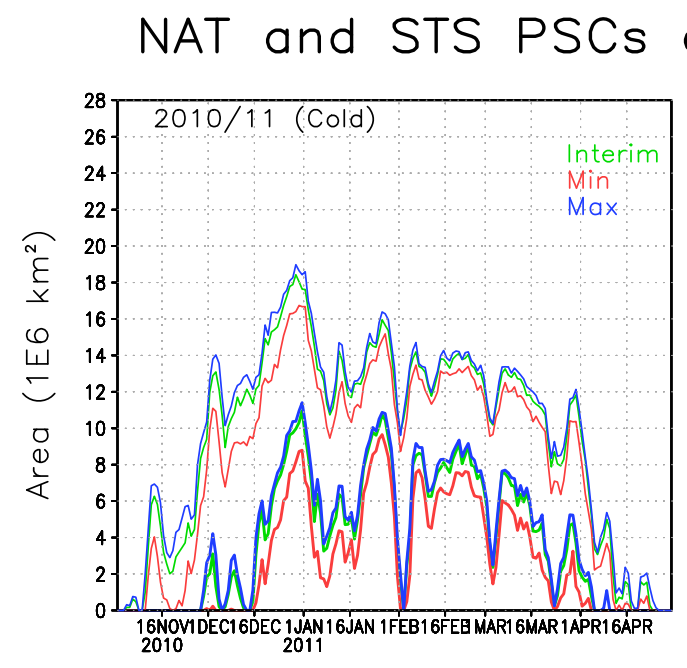

area $\left(1 \mathrm{E} 6 \mathrm{~km}^{2}\right), 55 \mathrm{hPa}$
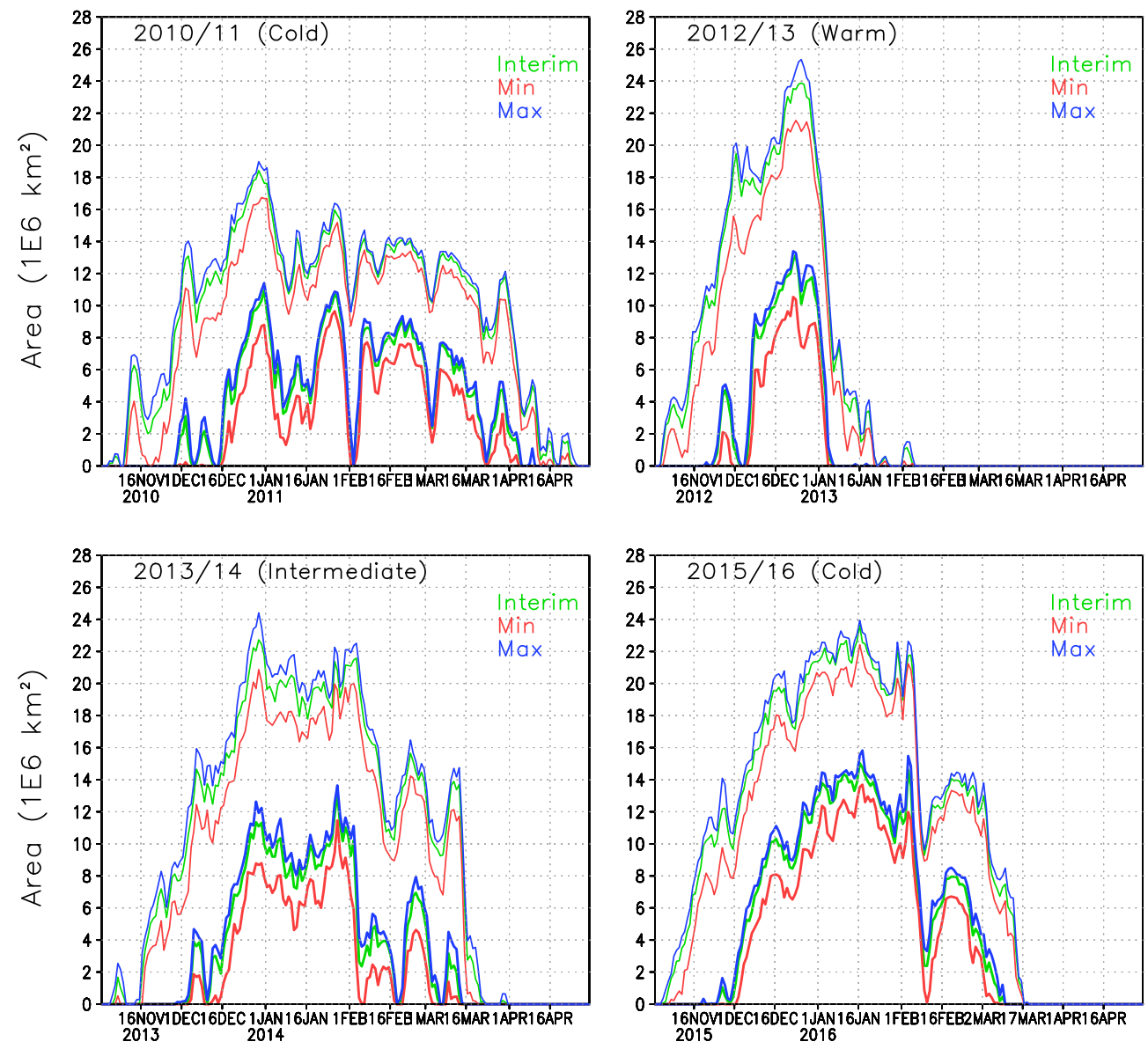

Figure 5. The area of NAT (thick lines) and STS PSCs (thin lines) $\left(10^{6} \mathrm{~km}^{2}\right)$ within the Arctic polar vortex in the simulations at $55 \mathrm{hPa}$. The green line denotes the Interim simulation, blue denotes the Max simulation and red denotes the Min simulation.

ROSE modelled ICE PSC areas (Thölix et al., 2016). The duration of ICE clouds being present is also comparable. However, Khosrawi et al. (2018) reported that a comparison showed that the PSC volume densities simulated with the EMAC model were several orders of magnitude smaller than the ones observed with MIPAS.

In the winter of 2012/2013 the polar vortex was very cold in December, and some ICE PSCs were simulated. However, after the SSW in early January no ICE PSCs were simulated, not even in the Max simulation. The winter of 2013/2014 was moderately cold, with some ICE PSC occurrence in late January. The winter of 2015/2016 started as being very cold in December and January, and the ICE PSC area was large throughout January. The maximum ICE PSC areas in the Interim simulation were about $70 \%$ larger compared to the other cold winter of 2010/2011. Dörnbrack et al. (2017) and Khosrawi et al. (2017) also reported unprecedented and widespread ICE PSC formation, seen in CALIPSO observa-
Table 1. Sum of the ICE, NAT and STS PSC areas $\left(10^{6} \mathrm{~km}^{2}\right.$ day $)$ at $55 \mathrm{hPa}$.

\begin{tabular}{llrrrr}
\hline & Year & $2010 / 11$ & $2012 / 13$ & $2013 / 14$ & $2015 / 16$ \\
\hline \multirow{2}{*}{ ICE } & Interim & 24 & 3 & 9 & 100 \\
& Min & 1 & 0 & 0 & 23 \\
& Max & 78 & 33 & 47 & 183 \\
\hline \multirow{2}{*}{ NAT } & Interim & 680 & 280 & 590 & 760 \\
& Min & 490 & 210 & 400 & 630 \\
& Max & 730 & 310 & 670 & 810 \\
\hline \multirow{2}{*}{ STS } & Interim & 1830 & 946 & 2110 & 2030 \\
& Min & 1770 & 850 & 1900 & 1890 \\
& Max & 2010 & 990 & 2230 & 2110
\end{tabular}

tions in 2015/2016. This was also the only winter with a significant ICE PSC area in the Min simulation, with a water vapour concentration of less than 4 ppmv. 
The water vapour concentration has a strong effect on the ICE PSC formation: in the Max simulations, the ICE PSC area increases significantly in all winters. For instance, in 2010/2011, the largest PSC area is more than twice as large in the Max as in the Interim simulation. In the warm winters (2012/2013 and 2013/2014) the relative increase in the ICE PSC area due to additional water vapour was even larger than in the cold winters (2010/2011 and 2015/2016). The amount of water vapour was also an important factor for the extent of ICE PSC occurrence in the winter of 2015/2016; however, the relative increase between the Interim and Max simulation was smaller than in other studied winters that were warmer. PSCs start to form about 2 weeks earlier in the Max simulation compared to the Interim simulation. In the Min simulation the stratosphere is too dry for ICE PSC formation in nearly all years.

Figure 5 shows the area of NAT and STS PSCs in the Arctic vortex. Both NAT and STS areas are always significantly larger than the ICE areas because type 1 PSCs form at warmer temperatures than ICE PSCs. Type 1 PSCs typically start to form in early November and ICE PSCs in midDecember to late December. The simulated peak values in the STS area range from 18 to 24 million $\mathrm{km}^{2}$, peaks in the NAT area range from 11 to 16 million $\mathrm{km}^{2}$, while the ICE area peaks range from 1.5 to 5.5 million $\mathrm{km}^{2}$ in the Interim simulation. As expected the type 1 PSCs occur later in the spring than ICE PSCs; e.g. in the winter of 2010/2011, both NAT and STS PSCs were simulated until late April, more than a month later than the ICE PSCs.

In the cold winter of 2010/2011, STS PSCs persisted for more than 5 months, and NAT almost 5 months, from December to mid-April. An increase in moisture (Max simulation) only had a minor effect on the NAT and STS areas. In the Min simulation the maximum STS (and NAT) area was about 2 million $\mathrm{km}^{2}$ smaller than in the Interim simulation, while the difference between the Max and Interim simulations was much smaller. In the winter of 2012/2013, both NAT and STS PSCs were only simulated in the beginning of the winter and by early January all the NAT PSCs disappeared due to warm conditions. The maximum value of STS area in the winter of 2012/2013 was the largest among the simulated years, 24 million $\mathrm{km}^{2}$. The maximum NAT area was also the largest, about 13 million $\mathrm{km}^{2}$. The increase of water vapour in the Max simulation did not change the PSC area as much as the decrease of water vapour in the Min simulation. In the early winter of 2012/2013 the NAT and STS areas were even larger than in 2010/2011, but warmer temperatures in the vortex in February caused the PSCs to diminish more rapidly. The effect of water vapour in 2012/2013 was the largest among the simulated years; the increase in NAT and STS areas between the Min and Interim simulations was about 3 million $\mathrm{km}^{2}$. In the winter of 2013/2014 both NAT and STS maximum areas were nearly as high as in 2012/2013 (about 23 and 11 million $\mathrm{km}^{2}$, respectively), but large areas of PSCs persist much longer than in the win- ter of 2012/2013. The maximum difference between Interim and Min simulation was about 2 million $\mathrm{km}^{2}$. In the winter of 2015/2016 the NAT and STS areas were also larger than in 2010/2011, but the PSCs did not persist as late as in 2010/2011. The increase in type 1 PSC area due to increased water vapour was smaller than in 2013/2014, about 1.5 million $\mathrm{km}^{2}$.

Table 1 shows cumulative ICE, NAT and STS PSC areas at $55 \mathrm{hPa}$. The largest cumulative ICE areas are always seen in the Max simulations. In the Min simulations there are only very small or no ICE PSC areas, with the exception of the winter of 2015/2016, when a considerable ICE PSC area was present in all runs. However, in 2015/2016 the ICE PSCs occurred mainly in December and January, while in 2010/2011 the ICE PSCs occurred from January until the end of February. The timing of the PSCs is important for chlorine activation and ozone loss as discussed later. The effect of water vapour on the cumulative ICE PSC area is larger in warm years than in cold years. The NAT and STS areas also strongly depend on winter temperatures - the maximum NAT and STS areas are simulated in the coldest winter of $2015 / 2016$ in every simulation, while the smallest areas are simulated during the warmest winter of 2012/2013. However, unlike ICE PSC, the NAT and STS clouds are formed every winter. The formation of type 1 PSCs is less sensitive to changes in water vapour concentration than the ICE PSCs. The relatively large changes in water vapour between different simulations result in relatively small changes in the cumulative NAT and STS area.

\subsection{Chlorine activation}

In early winter chlorine is present as reservoir compounds $\left(\mathrm{HCl}\right.$ and $\left.\mathrm{ClONO}_{2}\right)$, which do not destroy ozone. In the cold conditions within the polar vortex the chlorine species are transformed through heterogeneous reactions into intermediate species such as $\mathrm{Cl}_{2}$. When sunlight reaches the polar vortex these species are easily dissociated to form active chlorine species that participate in the catalytic ozone depletion cycles, i.e. $\mathrm{ClO}_{x}\left(\mathrm{ClO}, \mathrm{Cl}_{2} \mathrm{O}_{2}\right.$ and $\left.\mathrm{Cl}\right)$. Active chlorine is transformed back to reservoir species through reactions with $\mathrm{NO}_{2}$ and $\mathrm{CH}_{4}$; however if PSCs are present the regeneration of $\mathrm{ClO}_{x}$ is sustained.

Figure 6 shows the fraction of reservoir, intermediate and active chlorine species at $55 \mathrm{hPa}$ in the Min and Max simulations. The results from the Max simulation are represented by the upper limit for the intermediate (magenta) and active species (green) and by the lower limit for the reservoir species (black). The chlorine fractions from the Interim simulation always fit within the range of the Min and Max simulations. The timing of the changes in the partitioning of the chlorine species correlates well with the occurrence of PSCs; e.g. the chlorine reservoir species start to transform into intermediate species when the STS PSCs appear (Fig. 5). 
Table 2. Vortex-mean mixing ratio of $\mathrm{ClO}_{x}$ integrated over the whole winter (ppbv day) and as monthly mean concentration (ppbv) in the Min, Max and Interim simulations. Percentages in parentheses indicate the effect of SWV concentration changes compared to the Interim simulation.

\begin{tabular}{llrrrr}
\hline \multirow{2}{*}{ Winter } & Year & $\begin{array}{r}2010 / 11 \\
(\text { Cold })\end{array}$ & $\begin{array}{r}2012 / 13 \\
(\text { Warm })\end{array}$ & $\begin{array}{r}2013 / 14 \\
(\text { Intermediate })\end{array}$ & $\begin{array}{r}2015 / 16 \\
(\text { Cold })\end{array}$ \\
& Min & 152 & 73 & 113 & 119 \\
& Max & $145(-5 \%)$ & $72(-1 \%)$ & $101(-11 \%)$ & $117(-2 \%)$ \\
& $161+6 \%)$ & $76(+4 \%)$ & $120(+6 \%)$ & $123(+3 \%)$ \\
\hline \multirow{2}{*}{ Nov } & Interim & 0.12 & 0.12 & 0.11 & 0.12 \\
& Min & 0.14 & 0.13 & 0.12 & 0.14 \\
& Max & 0.13 & 0.13 & 0.12 & 0.13 \\
\hline \multirow{2}{*}{ Dec } & Interim & 0.35 & 0.74 & 0.28 & 0.43 \\
& Min & 0.41 & 0.79 & 0.38 & 0.48 \\
& Max & 0.36 & 0.72 & 0.34 & 0.43 \\
\hline \multirow{2}{*}{ Jan } & Interim & 1.4 & 0.94 & 1.28 & 1.59 \\
& Min & 1.49 & 1 & 1.43 & 1.61 \\
& Max & 1.36 & 0.98 & 1.34 & 1.55 \\
\hline \multirow{2}{*}{ Feb } & Interim & 1.5 & 0.22 & 1.03 & 1.23 \\
& Min & 1.59 & 0.23 & 1.22 & 1.28 \\
& Max & 1.56 & 0.23 & 1.17 & 1.25 \\
\hline Mar & Interim & 1.21 & 0.17 & 0.52 & 0.41 \\
& Min & 1.35 & 0.18 & 0.71 & 0.48 \\
& Max & 1.31 & 0.18 & 0.66 & 0.46 \\
\hline \multirow{2}{*}{ Apr } & Interim & 0.26 & 0.14 & 0.14 & 0.052 \\
& Min & 0.38 & 0.15 & 0.14 & 0.054 \\
& Max & 0.34 & 0.14 & 0.14 & 0.053 \\
\hline
\end{tabular}

In the 2010/2011 winter chlorine activation starts in the latter half of December and the fraction of $\mathrm{ClO}_{x}$ is large through the January-March period, reaching a maximum of about $85 \%$. The active chlorine starts to transform back to reservoir species (mainly $\mathrm{ClONO}_{2}$ ) in the beginning of March. In early April when the PSCs disappear, the active chlorine rapidly decreases to background values.

In the winter of 2012/2013 chlorine activation starts slightly earlier than in the other years, but already in the beginning of February most of the chlorine has converted back to the reservoir species due to a SSW. The maximum fraction of $\mathrm{ClO}_{x}$ is about $75 \%$, and is already reached at the end of December. The active chlorine decreased during January, and in the beginning of February the concentration reached nearly background values.

The beginning of the winter of 2013/2014 was very cold, the chlorine activation started in mid-December and the maximum chlorine activation was already reached at the end of January. After that, the vortex temperature increased and chlorine transformed back to reservoir species. The maximum fraction of $\mathrm{ClO}_{x}$ was slightly lower than in cold winters, about $70 \%$.

The winter of 2015/2016 started similar to the cold winter of 2010/2011 and nearly all of the chlorine was acti- vated at the beginning of January, but the deactivation already started at the end of January, making the period with high $\mathrm{ClO}_{x}$ shorter than in the winter of 2010/2011. At the end of February the vortex temperature increased and chlorine transformed back to reservoir species. The maximum fraction of the activated chlorine of about $80 \%$ was reached by the beginning of January.

The water vapour concentration seems to strongly affect the transformation of chlorine from the reservoir species to the intermediate ones in the beginning of the Arctic winter. The fractions of intermediate and reservoir chlorine species change significantly with water vapour concentration during November and December. The water vapour concentration affects the composition of binary aerosols and STS. When more water condenses to the particles the uptake coefficients for the heterogeneous reactions and the surface area increase; i.e., the reaction rates increase. The difference between Min and Max simulations can be up to $30 \%$ when about half of the reservoir chlorine have transformed to intermediate species, just before the concentration of active chlorine species starts to increase. The difference in concentration of active chlorine and reservoir species between the Min and Max simulations is smallest during the cold periods, due to heterogeneous chemistry on the PSCs (Fig. 6). The cold 


\section{Chlorine partitioning at $55 \mathrm{hPa}$}
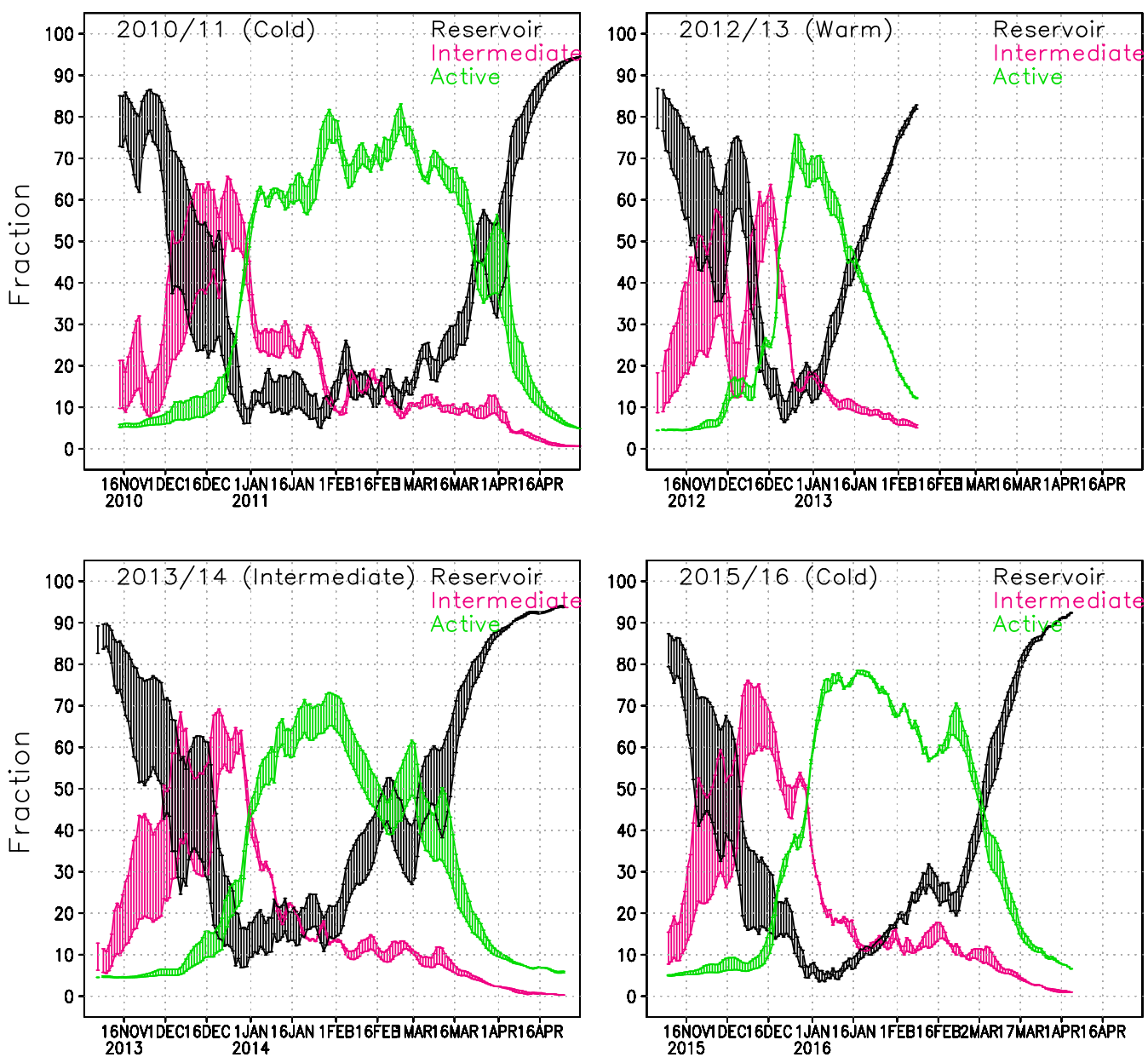

Figure 6. Chlorine partitioning (\%) within the Arctic polar vortex at $55 \mathrm{hPa}$ in the Min and Max simulations. Active form (green) is $\mathrm{Cl}+$ $\mathrm{ClO}+2 \times \mathrm{Cl}_{2} \mathrm{O}_{2}$. Intermediate (magenta) contains $2 \times \mathrm{Cl}_{2}+\mathrm{HOCl}+\mathrm{OClO}+\mathrm{BrCl}+\mathrm{ClNO}_{2}$ and reservoir chlorine (black) $\mathrm{HCl}+\mathrm{ClONO}$.

winter of 2015/2016 shows a very small range, and the intermediately cold winter of 2013/2014 shows a wider range in concentrations. The water vapour content has less effect on the chlorine partitioning in cold winters. In the cold spring of 2011 the difference in chlorine activation between Min and Max simulations was about $5 \%$ on average; it reached nearly $20 \%$ at the beginning of April, when the chlorine deactivation was fast. In the warm winter of 2012/2013 the change was less significant, about $5 \%$ during the winter. In the winter of 2013/2014 the difference in chlorine activation between Min and Max simulations reached $10 \%$ in the latter half of January; from mid-February to mid-March the difference was $15-18 \%$. The chlorine activation in the winter of 2015/2016 seemed to be less dependent on water vapour content, probably due to the ICE PSCs that appear in all simulations. Therefore, the conditions were favourable for high chlorine activation in all simulations. The difference in the fraction of activated chlorine between simulations is only a few percents; only when the deactivation starts (in the end of February) is the difference more than $5 \%$.

The effect of increased water vapour seems to be large in moderately cold years, i.e. when the chlorine activation is not entirely complete. The start and end of chlorine activation correlate with the appearance of STS and NAT. The ICE PSCs did not significantly increase the chlorine activation. For example in the winters of 2012/2013 and 2013/2014 there were no ICE PSCs in the Min simulation, but the chlorine activation was nearly as high as in the Max simulation, which had ICE PSCs.

Table 2 shows the vortex-averaged $\mathrm{ClO}_{x}$ as a cumulative sum over the whole winter and as monthly mean concentration. The sums are integrated from November to April. The cumulative sum provides information about both the duration of the chlorine activation period and the concentration 


\section{$\mathrm{ChemO}_{3} \mathrm{t}(\mathrm{DU})$ in vortex}
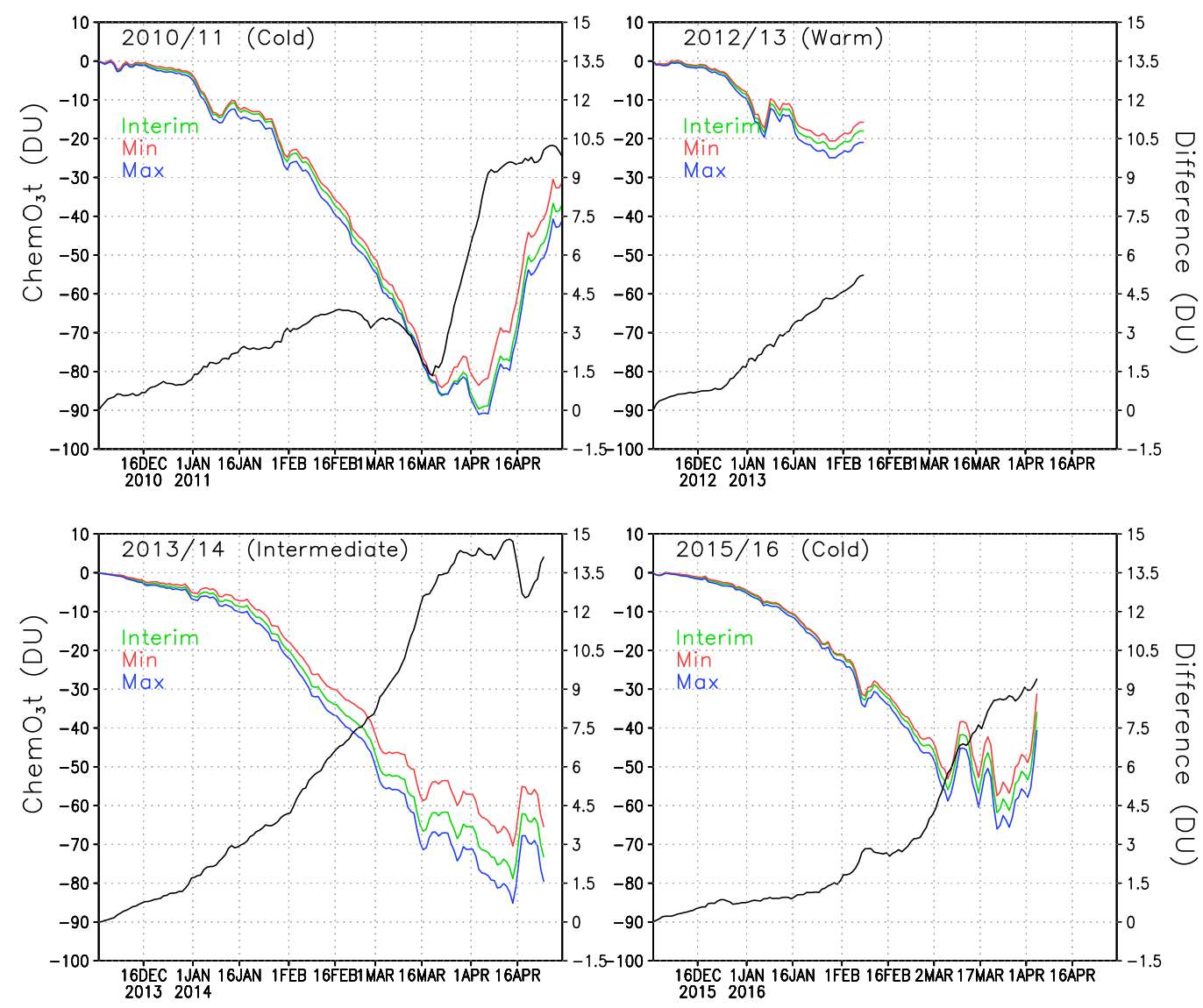

Figure 7. Chemical total ozone loss (DU) and difference between ozone loss in the Min and Max simulations within the Arctic polar vortex. The green line denotes the Interim simulation, blue denotes the Max simulation and red denotes the Min simulation. The difference is in black.

of $\mathrm{ClO}_{x}$, while the monthly average concentration shows the timing of chlorine activation. The cumulative chlorine activation was largest in the winter of 2010/2011 and smallest in 2012/2013. The activation started in November every year, but remained small until December. The winter of 2010/2011 differs from the others, with high chlorine activation from January to March, giving the largest cumulative sum of the studied winters. Even in April, the $\mathrm{ClO}_{x}$ concentration remains elevated. The warm winter of 2012/2013 had the smallest cumulative chlorine activation; significant chlorine activation was only seen in December and January. The changes in water vapour between the Min/Interim/Max simulations had the largest effect on the cumulative $\mathrm{ClO}_{x}$ in moderately cold winters (2010/2011 and 2013/2014), for which the increase of $\mathrm{ClO}_{x}$ from Interim to Max was $3 \%$ to $6 \%$ and the change of $\mathrm{ClO}_{x}$ from Interim to Min was $-1 \%$ to $-11 \%$. In the cold winter of 2015/2016 the respective changes were only $3 \%$ and $-2 \%$, and in the warm winter of 2012/2013 the changes were $4 \%$ and $-1 \%$.

\subsection{Ozone loss}

Figure 7 shows the mean chemical total ozone loss within the polar vortex for all the studied winters of 2010/2011, 2012/2013, 2013/2014 and 2015/2016. The total column chemical ozone loss was calculated by subtracting the passive transported total ozone from the modelled total ozone. In Fig. 7 the polar vortex is defined using the potential vorticity limit of $36 \mathrm{PVU}$, only at the $475 \mathrm{~K}$ level. The figure shows the chemical ozone depletion in the Interim, Min and Max simulations as well as the difference in the loss between the Min and Max simulations. The passive ozone tracer was initialized every year on 1 December, when it was set equal to the ozone distribution in the model on that day. Chemical processes start to reduce ozone already in December, but they have a minor effect on the total wintertime ozone loss. In January the chemical processes become more intensive when the chlorine activation increases (see Fig. 6).

In general the ozone loss is larger in cold years. The largest ozone loss was simulated in the beginning of April 2011 
when about 90 DU ozone had been destroyed according to our model. FinROSE seems to underestimate the ozone loss; for example, Sinnhuber et al. (2011) and Manney et al. (2011) simulated 120 DU ozone loss and Pommereau et al. (2013) even simulated 170 DU in the winter of 2010/2011. If we look at maximum ozone losses instead of the polar vortex mean losses, then the numbers are larger. The maximum ozone loss in 2010/2011 within the polar vortex was 128 DU, which is comparable to the value given by Sinnhuber et al. (2011).

The ozone loss in the warm winter of 2012/2013 differs from the loss in colder winters (2010/2011 and 2015/2016). The maximum average ozone loss in the polar vortex in the winter of 2012/2013 was only 23 DU because the polar vortex was unstable and small. By mid-April 2014 the simulated vortex mean ozone loss was $79 \mathrm{DU}$ in the Interim simulation. Before mid-February, i.e. during the coldest period, there was very little effect from the changes in SWV. A relatively small ozone loss of 56 DU was simulated in 2015/2016, which was due to the unstable polar vortex, which split and warmed, stopping the catalytic ozone cycles and ozone loss in the beginning of March, i.e. earlier than in 2010/2011 and 2013/2014.

Figure 7 also shows the difference of polar vortex averaged chemical ozone loss between Min and Max simulation. It shows how much the water vapour concentration change affects the ozone loss. The difference is largest (about 15 DU) in 2013/2014, a moderately cold winter, with significant ozone depletion. Another winter, 2010/2011, with significant ozone loss and cold, but not extremely cold conditions showed the second largest effect from addition of water vapour, about 10 DU. In 2012/2013, when the ozone loss stopped very early, the difference between Min and Max simulations was about 5 DU. The winter of 2015/2016 started as very cold, but was ended early by a SSW. The difference in ozone loss between the simulations remained very small up to mid-February; by mid-March the difference was about 7.5 DU. A reduction in the water vapour decreased ozone loss every winter. In the Interim simulation the deepest ozone losses were about 2-9DU (6\%-11\%) deeper than in the Min-simulation. The effect from an increase in water vapour from Interim to Max was about the same. In the 2010/2011 winter the loss increased by about $7 \%$, while Sinnhuber et al. (2011) and Vogel et al. (2011) reported an increase of ozone loss by $20 \%$ and $10 \%$ (respectively) with a water vapour increase of about the same magnitude as considered here. Thus, our estimates are slightly smaller than those by Vogel et al. (2011). An additional sensitivity experiment showed that the difference compared to other studies can be, at least partly, due to the coarse horizontal resolution in FinROSE $\left(3^{\circ} \times 6^{\circ}\right)$, which is not sufficient to fully capture the deepest ozone loss. Specifically, repeating Interim simulation for winter of $2010 / 11$ with higher resolution $\left(1.5^{\circ} \times 3^{\circ}\right)$ than in the original simulation showed larger ozone loss by $15 \mathrm{DU}$.
The changes in the amount of water vapour are in the range that was tested here and are not very important for ozone loss in cold years. In the 2010/2011 winter the chlorine activation was nearly complete in the Arctic polar vortex, and additional water vapour did not increase chlorine activation and thus did not increase the ozone depletion. Increasing water vapour concentration (compared to the Interim simulation) strengthens ozone loss by at least $4 \mathrm{DU}$ for other winters, except for the 2011 winter when the increase was not significant.

To better understand the mechanism of SWV influence on ozone loss, simulations without heterogeneous chemistry were performed. From those simulations ozone loss caused by heterogeneous chemistry can be separated by subtracting the total ozone simulated without heterogeneous chemistry from that simulated in the full chemistry run. Two different set-ups were used for testing the effect of the heterogeneous chemistry. In the first gas-phase chemistry simulation the heterogeneous chemistry was not included at all. In the second simulation the formation of PSCs was limited by setting the air temperature passed to the heterogeneous chemistry module to $200 \mathrm{~K}$, similarly to what was done in Karpechko et al. (2013). The increase of water vapour (Max simulation) did not increase the ozone loss, but in the Min simulation ozone depletion was reduced by $6 \mathrm{DU}$. This setting allows some heterogeneous processing on binary aerosols and some STS droplets that are very dilute in $\mathrm{HNO}_{3}$, and due to the temperature limit, the surface area densities will remain quite small. Table 3 summarizes ozone loss characteristics during the studied years and shows the loss produced by full chemistry, heterogeneous chemistry and separately by the NAT, STS and ICE PSCs in the Interim, Min and Max simulations.

In the Interim simulation with full chemistry in 2010/2011 about $90 \mathrm{DU}$ ozone was depleted, of which the heterogeneous chemistry caused depletion of 56 DU, i.e. about $62 \%$ of the total ozone loss. Heterogeneous chemistry due to PSCs destroyed 30 DU ozone, which was about $33 \%$ of the total loss. The result indicates that chlorine activation on the binary aerosols has a significant role in ozone depletion. Some studies suggest that binary aerosols are more important for chlorine activation than PSCs (e.g. Drdla and Müller, 2012; Wohltmann et al., 2013; Kirner et al., 2015). The increase of water vapour (Max simulation) did not increase the ozone loss, but in the Min simulation there was 6DU less ozone depletion. This is consistent with the results by Kirner et al. (2015), who argue that the contribution of ICE PSCs to the ozone loss is always less than $5 \%$ in the Antarctic spring, where the chlorine activation is nearly complete.

In the warm winter of 2012/2013 the ozone loss is only $23 \mathrm{DU}$, and the heterogeneous part is $63 \%$ of it. NAT, STS and ICE PSCs only caused a small part of the total heterogeneous-chemistry-driven ozone loss (24\%). The loss caused by heterogeneous chemistry increased with increasing water vapour, but remained small even in the Max simulation. In 2013/2014 the heterogeneous chemistry caused 
Table 3. Maximum polar vortex mean ozone loss produced by full chemistry, heterogeneous chemistry and separately by the STS, NAT and ICE part in Min, Max and Interim simulations (DU). Percentages show the fraction due to each part relative to the full chemistry.

\begin{tabular}{llrrrr}
\hline & Year & $\begin{array}{r}2010 / 11 \\
(\text { Cold })\end{array}$ & $\begin{array}{r}2012 / 13 \\
(\text { Warm })\end{array}$ & $\begin{array}{r}2013 / 14 \\
(\text { Intermediate })\end{array}$ & $\begin{array}{r}2015 / 16 \\
(\text { Cold })\end{array}$ \\
\hline \multirow{2}{*}{ Min } & Full chemistry & 84 & 21 & 70 & 53 \\
& Heterogeneous part & $50(60 \%)$ & $13(62 \%)$ & $32(45 \%)$ & $33(62 \%)$ \\
& STS, NAT and ICE & $20(24 \%)$ & $3(15 \%)$ & $13(19 \%)$ & $11(21 \%)$ \\
\hline \multirow{2}{*}{ Interim } & Full chemistry & 90 & 23 & 79 & 56 \\
& Heterogeneous part & $56(62 \%)$ & $14(63 \%)$ & $40(51 \%)$ & $35(63 \%)$ \\
& STS, NAT and ICE & $30(33 \%)$ & $5(24 \%)$ & $23(30 \%)$ & $17(30 \%)$ \\
\hline \multirow{2}{*}{ Max } & Full chemistry & 91 & 25 & 85 & 59 \\
& Heterogeneous part & $56(62 \%)$ & $15(62 \%)$ & $45(53 \%)$ & $37(63 \%)$ \\
& STS, NAT and ICE & $34(37 \%)$ & $7(28 \%)$ & $30(35 \%)$ & $19(33 \%)$ \\
\hline
\end{tabular}

about $40 \mathrm{DU}$ ozone destruction, which is about $51 \%$ of the ozone loss and NAT, STS and ICE about 23 DU (30\%), when the total ozone loss was $79 \mathrm{DU}$ in the Interim run. The increase in SWV from Interim to Max increased the ozone loss by about $6 \mathrm{DU}$ and the decrease in SWV from Min to Interim decreased the ozone loss by $9 \mathrm{DU}$. Thus, water vapour changes have a larger effect on ozone loss in moderately cold years than in cold ones. The ozone depletion due to heterogeneous chemistry increased with water vapour, even though the fraction due to heterogeneous chemistry was smaller than in 2010/2011 and 2015/2016.

In the winter of 2015/2016 the heterogeneous contribution was largest when compared to other simulated years, reaching even $63 \%$ of the ozone loss, and the STS, NAT and ICE part was also large, at $30 \%$. The total ozone loss is however only $56 \mathrm{DU}$. When the water vapour content was increased from Interim to Max simulations, the fraction due to the heterogeneous chemistry remained the same, but the fraction due to STS, NAT and ICE PSCs increased.

Based on the results in Table 3 it can be concluded that nearly all SWV impact on ozone loss is due to heterogeneous chemistry. For example in 2010/2011 the ozone loss without heterogeneous chemistry was $34 \mathrm{DU}$ in Interim, $34 \mathrm{DU}$ in Min and $35 \mathrm{DU}$ in Max simulation and only the heterogeneous part changed from model run to model run. In 2013/2014 the non-heterogeneous contribution is about $39 \mathrm{DU}$, and in $2015 / 2016$ about 21 DU; i.e. in warm years it is larger than in cold years. In 2012/2013 the nonheterogeneous contribution was only $9 \mathrm{DU}$, but also the total ozone loss is very small. However, the heterogeneous contribution is about $62 \%$ of the total ozone loss in all other winters than 2013/2014 and also with both increased and decreased water vapour. The fraction of STS-, NAT- and ICEdriven chemistry changes with water vapour concentration.

Finally we analyse the vertical distribution of the ozone loss and the effect of SWV on ozone loss, which is shown in Fig. 8. The largest ozone loss was simulated in 2010/2011, when the ozone destruction in the Interim run with nor- mal SWV was about $1.4 \mathrm{ppmv}$ between 60 and $30 \mathrm{hPa}$. The ozone depletion increased by 0.2 ppmv between the Min and Max simulations. In 2012/2013 the maximum ozone reduction was almost the same as in 2010/11, but it occurred at higher altitude and lasts for a shorter period than in 2011. The effect of the increase in water vapour from Min to Max simulations only had a minor effect on the ozone depletion in 2012/2013. The heterogeneous chemistry and chlorine activation did not have an important role in the warm conditions, and the ozone loss between 60 and $30 \mathrm{hPa}$ remains very weak. In winters when the polar vortex is unstable and small or disturbed, the Brewer-Dobson circulation brings more $\mathrm{NO}_{x}$-rich air into the polar vortex than usual. Hence the ozone loss in the winter of 2012/2013 was mostly produced by $\mathrm{NO}_{x}$ chemistry as shown previously by, e.g. Sagi et al. (2017), and can be seen from FinROSE results by comparing the simulations with and without the heterogeneous chemistry. The total ozone column loss in this winter remained smaller than in cold years, when the ozone depletion is driven by halogens. In the 2014 spring the conditions in the polar vortex remained favourable, but the temperature was not as low as in 2011. The ozone loss developed steadily, but remained moderate. The two winters of 2010/2011 and 2013/2014 with the most favourable conditions for halogendriven ozone depletion showed the largest increase in ozone loss with water vapour. The effect was more pronounced in 2013/2014, which was the warmer of the two winters. The winters of 2010/11 and 2015/2016 look similar during January-February, but the ozone loss became much more severe in 2010/2011 due to favourable conditions in MarchApril. In 2015/2016 there was a very cold period, but it occurred too early to have a large impact on the ozone depletion, and therefore the water vapour increase only had a moderate effect later in the spring. In 2013/2014 the largest ozone loss was about $1.1 \mathrm{ppmv}$ between 60 and $30 \mathrm{hPa}$, while in $2015 / 2016$ it was about 1 ppmv at the same altitude. Livesey et al. (2015) and Sagi et al. (2017) showed results from the $450 \mathrm{~K}$ level, and their ozone losses were about 2 ppmv in 


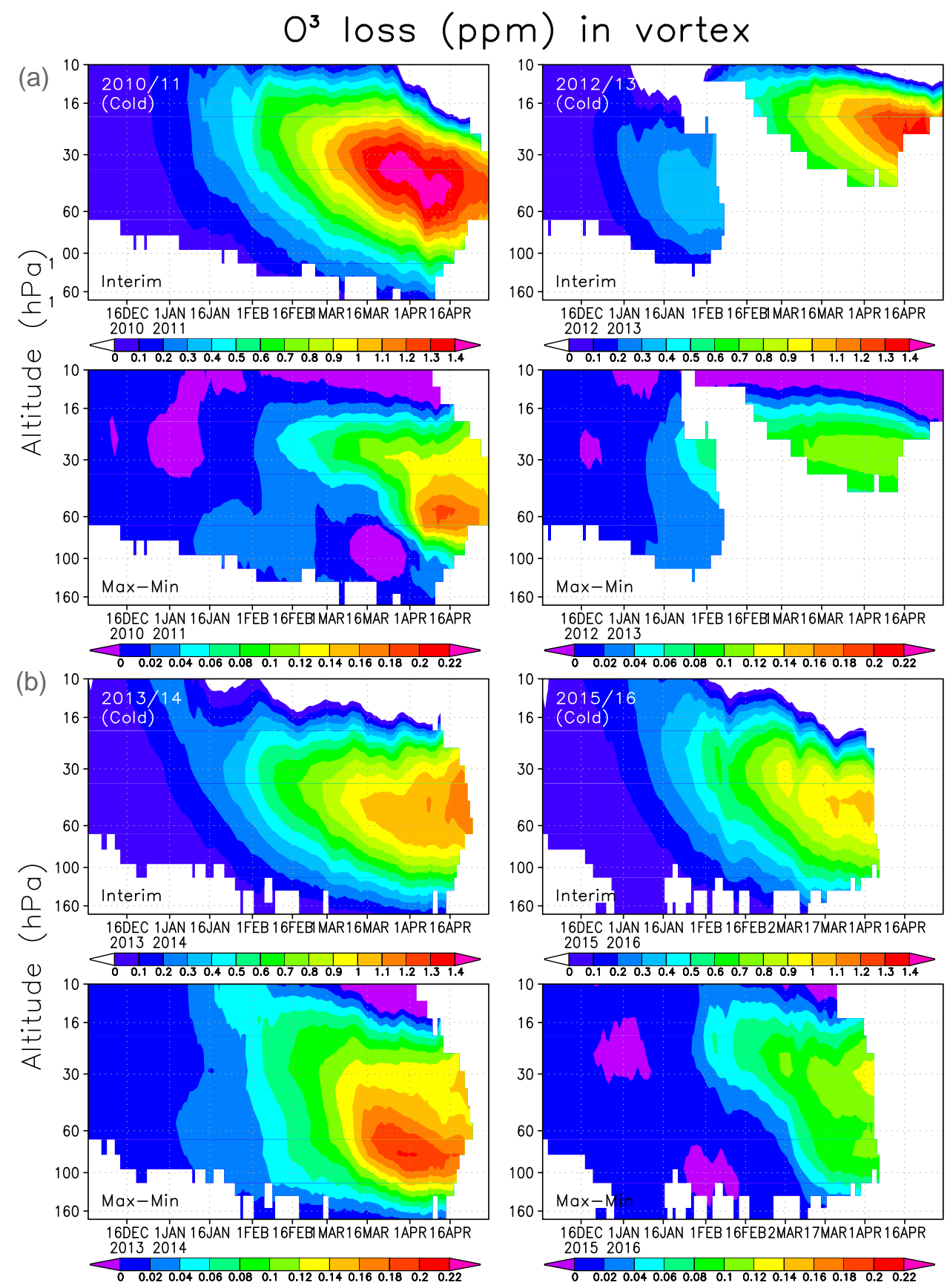

Figure 8. Averaged chemical ozone loss (ppmv) in the Interim simulation (a) and the difference between Max and Min simulations (b) within the Arctic polar vortex.

the winter of 2011. In the winter of 2013 Sagi et al. (2017) recorded about 1.5 ppmv ozone loss, which is about the same as what we found.

\section{Discussion and conclusions}

Khosrawi et al. (2016) showed that an increase in SWV and a cooling of the stratospheric temperature enhance each other, so that the area of PSCs increases and that these can last longer in the vortex. The ozone loss can thus increase although the halogen loading has been decreased. In this study, rather than artificially changing the temperature, we used 
meteorological fields from seven winters during the period 2010-2016 with different temperatures and dynamical conditions in the stratosphere. We changed the water vapour content in the tropical tropopause region according to the CCMVal-2 simulations. The water vapour entry concentration is controlled by the cold point in the TTL, and the distribution of SWV is largely determined by this entry concentration together with the transport and the contribution from methane oxidation. Our results show that, as expected, a wetter/drier tropical tropopause leads to a wetter/drier Arctic polar vortex, and also that the size of polar ozone depletion changes when the water vapour changes, which also affects Arctic ozone loss.

A reduction in SWV decreases the ozone loss due to heterogeneous processes by decreasing the PSC formation. An increase in SWV instead makes the heterogeneous chemistry more important. As expected, heterogeneous chemistry is less important in warm winters; i.e. in 2012/2013 only 14 DU ozone depletion was initiated by heterogeneous chemistry in the Interim simulation. The corresponding loss in the winter of 2010/11, with persistent cold conditions, was 56 DU. The increase in loss with water vapour was small; i.e. the loss increased from 50 to $56 \mathrm{DU}$ from the Min to the Max simulations. In the winter of 2012/2013 the corresponding losses were 32 and 45 DU; i.e. the water vapour concentration had the largest impact in moderately cold winters. If the winter is cold enough, the increase is less important because the PSCs may form, even at low water vapour concentrations, and the chlorine activation is already nearly complete in Arctic vortex; therefore the water vapour increase is less important.

Winters in the polar stratosphere are often divided into cold, or dynamically inactive, and warm, or dynamically active categories. In the cold Arctic winters the polar vortex is stable and more PSCs are formed and halogens can destroy ozone. Warm conditions in the polar winter stratosphere are often due to SSW, which allows $\mathrm{NO}_{x}$-rich air masses from the mesosphere to enter the vortex and take part in the ozone depletion (Sagi et al., 2017). Cold polar stratospheric winters differ from the warm winters regarding the ozone loss and the fraction of ozone loss initiated by heterogeneous chemistry; during cold stratospheric winters the PSC areas are larger and thus chlorine activation within the polar vortex is more complete. A lack of water leads to fewer ICE PSCs, and therefore to less $\mathrm{ClO}_{x}$. However, the ICE PSC area is not the only explaining factor for ozone loss. The type 1 PSCs that form at higher temperatures are responsible for a large fraction of the chlorine activation. The formation of STS and NAT is limited by the partial pressure of nitric acid, sulfuric acid and water, and hence the concentration of water vapour is not the only thing affecting the NAT and STS areas. However, the dry conditions in the Min simulations have some limiting effect on the peak NAT and STS areas.

The cold Arctic winter of 2010/2011 differs from the others by an especially long chlorine activation period, which leads to large ozone depletion. In the warm Arctic winter of 2012/2013 the polar vortex was weak; however it was shifted to the south where it was exposed to sunlight earlier than usual, and thus ozone loss could start earlier. The ozone loss was however weak because chlorine activation remained very low. The ozone depletion in 2012/2013 occurred at higher altitudes than in the other years because of the $\mathrm{NO}_{x}$-induced ozone loss. The 2013/2014 Arctic winter was moderately cold, and the ozone depletion was second largest among the considered winters. In this winter the effect of water vapour changes on ozone loss was the largest across the studied winters. The Arctic winter of 2015/2016 started as extremely cold (Matthias et al., 2016; Manney et al., 2016), but the polar stratosphere warmed early, terminating chlorine activation and leaving ozone loss relatively low, despite the fact that the cumulative ICE areas were extremely large.

Chemical ozone destruction inside the Arctic vortex varied between 23 and 90 DU in the Interim simulations, 25 and 91 DU in the Max simulations and 21 and 84 DU in the Min simulations. We find that the meteorological conditions are more important for the ozone depletion than the concentration of water vapour. The fraction of heterogeneous chemistry in the ozone loss is also more dependent on the temperature than on the water content. Livesey et al. (2015) came to a similar conclusion when investigating ozone loss based on the MLS observations.

MacKenzie and Harwood (2004) showed from their chemistry-climate model simulations that the increase of water vapour increases the area of PSCs, both by microphysical effects and due to lowering of the stratospheric temperatures. The microphysical processes cover about $20 \%$ of the increase and the rest is due to cooling of the polar stratosphere. In our study we only changed the water vapour concentration. However, the temperature effect can be seen by investigating different years. The cumulative ICE areas between studied years varied by a factor of 30 , and in cumulative NAT and STS by 2.7 and 2.2, respectively. MacKenzie and Harwood (2004) got about $15 \%$ more ozone loss at $465 \mathrm{~K}$ level with less than 1 ppmv additional water vapour without changing temperature. In our study the ozone loss increased by 1 DU ( $1 \%$ ) in $2010 / 2011,2$ DU (9\%) in 2012/2013, 6 DU $(8 \%)$ in $2013 / 2014$ and 3 DU (5\%) in 2015/2016 when the water vapour concentration was increased by about 2 ppmv. When the water vapour was instead decreased by about $1.5 \mathrm{ppmv}$, the ozone loss decreased by $6 \mathrm{DU}$ (7\%), $2 \mathrm{DU}$ $(9 \%), 9 \mathrm{DU}(11 \%)$ and $3 \mathrm{DU}(5 \%)$, respectively. The small contribution due to water vapour increase in the Arctic winter of 2010/11 can be compared to the results of MacKenzie and Harwood (2004) in the Antarctic vortex. There, the chlorine activation is nearly complete in every winter. In addition, in the Arctic winter of 2010/2011 nearly all chlorine in the polar vortex was activated, and additional water vapour did not change the activation, and thus not the ozone depletion either.

Note that effects of changing water vapour concentration on air temperature, not accounted for here, would probably 
have increased the impact of water vapour on ozone loss. The indirect impact comes through water vapour radiative impact on stratospheric temperatures. Tian et al. (2016) estimate that a 2 ppmv increase of water vapour would cool the polar stratosphere by approximately $2 \mathrm{~K}$, while Rex et al. (2004) estimate that a $1 \mathrm{~K}$ cooling could increase ozone loss in the Arctic by 15 DU. Thus based on these estimates, a water vapour increase of 2 ppmv, similar to the difference between Interim and Max runs, could result in up to $30 \mathrm{DU}$ additional ozone loss. This estimate suggests that the direct water vapour impact on ozone loss quantified in our experiments may account for only about one-fifth of the total ozone loss, but in order to confirm this estimation an experiment designed with a chemistry-climate model would be needed.

In summary, we find that variability of stratospheric water vapour of 3.5 ppmv, comparable in magnitude to uncertainty in simulated water vapour concentration near the tropical tropopause, results in differences in simulated Arctic ozone loss of up to $15 \mathrm{DU}$, i.e. more than $15 \%$ of the total chemical ozone loss in the Arctic vortex. Better understanding of tropical processes contributing to the stratospheric water vapour concentration, and thus constraining stratospheric water vapour, would therefore reduce the uncertainty in Arctic ozone loss and improve future projections of ozone layer recovery.

Data availability. Data from the FinROSE simulations are available from the authors upon request. The ERA-Interim dataset has been made available for download from the ECMWF website at http://www.ecmwf.int/en/research/climate-reanalysis/ era-interim (Dee et al., 2011). The Aura/MLS data are available from http://mirador.gsfc.nasa.gov (Lambert et al., 2007).

Author contributions. AK originally developed the idea of this study. LT, LB and AK designed the model simulations. LT performed the simulations and prepared the manuscript with contributions from the co-authors. LB and AK contributed to the discussion and interpretation of the results derived in this study. This study was done as a part of a research project, "Arctic upper tropospheric and lower stratospheric water vapor", led by RK. All the authors were involved in the final revision of the paper.

Competing interests. The authors declare that they have no conflict of interest.

Acknowledgements. We acknowledge ECMWF for providing us with the ERA-Interim reanalysis data. We would also like to thank the UARS reference atmosphere project and MLS/Aura teams for water vapour data. The MLS data were obtained from the NASA Goddard Earth Sciences and Information Center (http://mirador.gsfc.nasa.gov/; last access: 16 October 2018). Funding by the Academy of Finland through the UTLS project (140408) and by the EU through the project GAIA-CLIM is gratefully acknowledged.

Edited by: Farahnaz Khosrawi

Reviewed by: two anonymous referees

\section{References}

Atkinson, R., Baulch, D. L., Cox, R. A., Crowley, J. N., Hampson, R. F., Hynes, R. G., Jenkin, M. E., Rossi, M. J., and Troe, J.: Evaluated kinetic and photochemical data for atmospheric chemistry: Volume III - gas phase reactions of inorganic halogens, Atmos. Chem. Phys., 7, 981-1191, https://doi.org/10.5194/acp7-981-2007, 2007.

Bekki, S. and Pyle, J.: Two-dimensional assessment of the impact of aircraft sulphur emissions on the stratospheric sulphate aerosol layer, J. Geophys. Res., 9, 15839-15847, 1992.

Chipperfield, M. P., Dhomse, S. S., Feng, W., McKenzie, R. L., Velders, G. J. M., and Pyle, J. A.: Quantifying the ozone and ultraviolet benefits already achieved by the Montreal Protocol, Nat. Commun., 6, 7233, https://doi.org/10.1038/ncomms8233, 2015.

Chipperfield, M., Bekki, S., Dhomse, S., Harris, N., Hassler, B., Hossaini, R., Steinbrecht, W., Thiéblemont, R., and Weber, M.: Detecting recovery of the stratospheric ozone layer, Nature 549, 211-218, https://doi.org/10.1038/nature23681, 2017.

Dahlback, A. and Stamnes, K.: A new spherical model for computing the radiation field available for photolysis and heating at twilight, Planet. Space Sci., 39, 671-683, 1991.

Dameris, M., and Godin-Beekmann, S., Alexander, S., Braesicke, P., Chipperfield, M., de Laat, A. T. J., Orsolini, Y., Rex, M., and Santee, M. L.: Update on Polar ozone: Past, present, and future, Chapter 3 in Scientific Assessment of Ozone Depletion: 2014, Global Ozone Research and Monitoring Project - Report No. 55, World Meteorological Organization, Geneva, Switz erland, 2014.

Damski, J., Thölix, L., Backman, L., Kaurola, J., Taalas, P., Austin, J., Butchart, N., and Kulmala, M.: A chemistry-transport model simulation of middle atmospheric ozone from 1980 to 2019 using coupled chemistry GCM winds and temperatures, Atmos. Chem. Phys., 7, 2165-2181, https://doi.org/10.5194/acp-7-2165-2007, 2007a.

Damski, J., Thölix, L., Backman, L., Taalas, P., and Kulmala, M.: FinROSE - middle atmospheric chemistry and transport model, Boreal Environ. Res., 12, 535-550, 2007b.

Dee, D. P., Uppala, S. M., Simmons, A. J., Berrisford, P., Poli, P., Kobayashi, S., Andrae, U., Balmaseda, M. A., Balsamo, G., Bauer, P., Bechtold, P., Beljaars, A. C. M., van de Berg, L., Bidlot, J., Bormann, N., Delsol, C., Dragani, R., Fuentes, M., Geer, A. J., Haimberger, L., Healy, S. B., Hersbach, H., Holm, E. V., Isaksen, L., Kallberg, P., Kohler, M., Matricardi, M., McNally, A. P., Monge-Sanz, B. M., Morcrette, J.-J., Park, B.-K., Peubey, C., de Rosnay, P., Tavolato, C., Thepaut, J.-N., and Vitart, F.: The ERA-Interim reanalysis: configuration and performance of the data assimilation system, Q. J. Roy. Meteorol. Soc., 137, 553597, 2011.

Dessler, A. E., Schoeberl, M. R., Wang, T., Davis, S. M., and Rosenlof, K. H.: Stratospheric water vapor feedback, P. Natl. Acad. Sci. USA, 110, 18087-18091, https://doi.org/10.1073/pnas.1310344110, 2013. 
Dhomse, S. S., Kinnison, D., Chipperfield, M. P., Salawitch, R. J., Cionni, I., Hegglin, M. I., Abraham, N. L., Akiyoshi, H., Archibald, A. T., Bednarz, E. M., Bekki, S., Braesicke, P., Butchart, N., Dameris, M., Deushi, M., Frith, S., Hardiman, S. C., Hassler, B., Horowitz, L. W., Hu, R.-M., Jöckel, P., Josse, B., Kirner, O., Kremser, S., Langematz, U., Lewis, J., Marchand, M., Lin, M., Mancini, E., Marécal, V., Michou, M., Morgenstern, O., O’Connor, F. M., Oman, L., Pitari, G., Plummer, D. A., Pyle, J. A., Revell, L. E., Rozanov, E., Schofield, R., Stenke, A., Stone, K., Sudo, K., Tilmes, S., Visioni, D., Yamashita, Y., and Zeng, G.: Estimates of ozone return dates from ChemistryClimate Model Initiative simulations, Atmos. Chem. Phys., 18, 8409-8438, https://doi.org/10.5194/acp-18-8409-2018, 2018.

Dörnbrack, A., Gisinger, S., Pitts, M. C., Poole, L. R., and Maturilli, M.: Multilevel cloud structures over Svalbard, Mon. Weather. Rev., 145, 1149-1159, https://doi.org/10.1175/mwr-d16-0214.1, 2017.

Drdla, K. and Müller, R.: Temperature thresholds for chlorine activation and ozone loss in the polar stratosphere, Ann. Geophys., 30, 1055-1073, https://doi.org/10.5194/angeo-30-10552012, 2012.

Dvortsov, V. L. and Solomon, S.: Response of the stratospheric temperatures and ozone to past and future increases in stratospheric humidity, J. Geophys. Res., 106, 7505-7514, 2001.

Engel, A., Bönisch, H., Ostermöller, J., Chipperfield, M. P., Dhomse, S., and Jöckel, P.: A refined method for calculating equivalent effective stratospheric chlorine, Atmos. Chem. Phys., 18, 601-619, https://doi.org/10.5194/acp-18-601-2018, 2018.

Eyring, V., et al.: Multimodel projections of stratospheric ozone in the 21 st century, J. Geophys. Res., 112, D16303, https://doi.org/10.1029/2006JD008332, 2007.

Eyring, V., Cionni, I., Bodeker, G. E., Charlton-Perez, A. J., Kinnison, D. E., Scinocca, J. F., Waugh, D. W., Akiyoshi, H., Bekki, S., Chipperfield, M. P., Dameris, M., Dhomse, S., Frith, S. M., Garny, H., Gettelman, A., Kubin, A., Langematz, U., Mancini, E., Marchand, M., Nakamura, T., Oman, L. D., Pawson, S., Pitari, G., Plummer, D. A., Rozanov, E., Shepherd, T. G., Shibata, K., Tian, W., Braesicke, P., Hardiman, S. C., Lamarque, J. F., Morgenstern, O., Pyle, J. A., Smale, D., and Yamashita, Y.: Multimodel assessment of stratospheric ozone return dates and ozone recovery in CCMVal-2 models, Atmos. Chem. Phys., 10, 94519472, https://doi.org/10.5194/acp-10-9451-2010, 2010.

Feck, T., J.-U. Grooß, and M. Riese: Sensitivity of Arctic ozone loss to stratospheric $\mathrm{H}_{2} \mathrm{O}$, Geophys. Res. Lett., 35, L01803, https://doi.org/10.1029/2007GL031334, 2008.

Fueglistaler, S. and Haynes, P. H.: Control of interannual and longer-term variability of stratospheric water vapor, J. Geophys. Res., 110, 1-14, https://doi.org/10.1029/2005JD006019, 2005.

Gettelman, A., Hegglin, M. I., Son, S. W., Kim, J., Fujiwara, M., Birner, T., Kremser, S., Rex, M., Añel, J. A., Akiyoshi, H., Austin, J., Bekki, S., Braesike, P., Brühl, C., Butchart, N., Chipperfield, M., Dameris, M., Dhomse, S., Garny, H., Hardiman, S. C., Jöckel, P., Kinnison, D. E., Lamarque, J. F., Mancini, E., Marchand, M., Michou, M., Morgenstern, O., Pawson, S., Pitari, G., Plummer, D., Pyle, J. A., Rozanov, E., Scinocca, J., Shepherd, T. G., Shibata, K., Smale, D., Teyssèdre, H., and Tian, W.: Multimodel assessment of the upper troposphere and lower stratosphere: Tropics and global trends, J. Geophys. Res., 115, D00M08, https://doi.org/10.1029/2009JD013638, 2010.
Hamill, P., Jensen, E. J., Russell, P. B., and Bauman, J. J.: The life cycle of stratospheric aerosols, B. Am. Meteorol. Soc., 78, 13951410, 1997.

Karpechko, A.Yu., Backman, L., Thölix, L., Ialongo, I., Andersson, M., Fioletov, V., Heikkilä, A., Johnsen, B., Koskela, T., Kyrölä, E., Lakkala, K., Myhre, C. L., Rex, M., Sofieva, V. F., Tamminen, J., and Wohltmann, I.: The link between springtime total ozone and summer UV radiation in Northern Hemisphere extratropics, J. Geophys. Res., 118, 8649-8661, https://doi.org/10.1002/jgrd.50601, 2013.

Khosrawi, F., Urban, J., Lossow, S., Stiller, G., Weigel, K., Braesicke, P., Pitts, M. C., Rozanov, A., Burrows, J. P., and Murtagh, D.: Sensitivity of polar stratospheric cloud formation to changes in water vapour and temperature, Atmos. Chem. Phys., 16, 101-121, https://doi.org/10.5194/acp-16-101-2016, 2016.

Khosrawi, F., Kirner, O., Sinnhuber, B.-M., Johansson, S., Höpfner, M., Santee, M. L., Froidevaux, L., Ungermann, J., Ruhnke, R., Woiwode, W., Oelhaf, H., and Braesicke, P.: Denitrification, dehydration and ozone loss during the 2015/2016 Arctic winter, Atmos. Chem. Phys., 17, 1289312910, https://doi.org/10.5194/acp-17-12893-2017, 2017.

Khosrawi, F., Kirner, O., Stiller, G., Höpfner, M., Santee, M. L., Kellmann, S., and Braesicke, P.: Comparison of ECHAM5/MESSy Atmospheric Chemistry (EMAC) simulations of the Arctic winter 2009/2010 and 2010/2011 with Envisat/MIPAS and Aura/MLS observations, Atmos. Chem. Phys., 18, 8873-8892, https://doi.org/10.5194/acp-18-88732018, 2018.

Kim, J., Randel, W. J., and Birner, T.: Convectively Driven Tropopause-Level Cooling and Its Influences on Stratospheric Moisture, J. Geophys. Res., 123, 590-606, https://doi.org/10.1002/2017JD027080, 2018.

Kirk-Davidoff, D. B., Anderson, J. G., Hintsa, E. J., and Keith, D. W.: The effect of climate change on ozone depletion through changes in stratospheric water vapour, Nature, 402, 399401, 1999.

Kirner, O., Müller, R., Ruhnke, R., and Fischer, H.: Contribution of liquid, NAT and ice particles to chlorine activation and ozone depletion in Antarctic winter and spring, Atmos. Chem. Phys., 15, 2019-2030, https://doi.org/10.5194/acp-15-2019-2015, 2015.

Kuttippurath, J. and Nair, P. J.: The signs of Antarctic ozone hole recovery, Sci. Rep., 7, 585, https://doi.org/10.1038/s41598-01700722-7, 2017.

Kylling, A., Stamnes, K., and Tsay, S.-C.: A reliable and efficient two-stream algorithm for radiative transfer; Documentation of accuracy in realistic layered media, J. Atmos. Chem., 21, 115150, 1995.

Lait, L. R.: An alternative form for potential vorticity, J. Atmos. Sci., 51, 1754-1759, 1994.

Lambert, A., Read, W. G., Livesey, N. J., Santee, M. L., Manney, G. L., Froidevaux, L., Wu, D. L., Schwartz, M. J., Pumphrey, H. C., Jimenez, C., Nedoluha, G. E., Cofield, R. E., Cuddy, D. T., Daffer, W. H., Drouin, B. J., Fuller, R. A., Jarnot, R. F., Knosp, B. W., Pickett, H. M., Perun, V. S., Snyder, W. V., Stek, P. C., Thurstans, R. P., Wagner, P. A., Waters, J. W., Jucks, K. W., Toon, G. C., Stachnik, R. A., Bernath, P. F., Boone, C. D., Walker, K. A., Urban, J., Murtagh, D., Elkins, J. W., and Atlas, E.: Validation of the Aura Microwave Limb Sounder middle atmosphere water vapor and 
nitrous oxide measurements, J. Geophys. Res., 112, D24S36, https://doi.org/10.1029/2007JD008724, 2007.

Lin, S.-J. and Rood, R. B.: Multidimensional flux-form semilagrangian transport schemes, Mon. Weather Rev., 124, 20462070, 1996.

Livesey, N. J., Santee, M. L., and Manney, G. L.: A Matchbased approach to the estimation of polar stratospheric ozone loss using Aura Microwave Limb Sounder observations, Atmos. Chem. Phys., 15, 9945-9963, https://doi.org/10.5194/acp15-9945-2015, 2015.

MacKenzie, I. A., and Harwood, R. S.: Middle-atmospheric response to a future increase in humidity arising from increased methane abundance, J. Geophys. Res., 109, D02107, https://doi.org/10.1029/2003JD003590, 2004.

Manney, G. L., Santee, M. L., Rex, M., Livesey, N. L., Pitts, M. C., Veefkind, P., Nash, E. R., Woltmann, I., Lehmann, R., Froidevaux, L., Poole, L. R., Schoeberl, M. R., Haffner, D. P., Davies, J., Dorokhov, V., Gernandt, H., Johnson, B., Kivi, R., Kyrö, E., Larsen, N., Levelt, P. F., Makshtas, A., McElroy, C. T., Nakajima, H., Concepcion Parrondo, M., Tarasick, D. W., von der Gathen, P., Walker, K. A., and Zinoviev, N. S.: Unprecedented Arctic ozone loss in 2011, Nature, 478, 469-475, https://doi.org/10.1038/nature10556, 2011.

Manney, G. L. and Lawrence, Z. D.: The major stratospheric final warming in 2016: dispersal of vortex air and termination of Arctic chemical ozone loss, Atmos. Chem. Phys., 16, 15371-15396, https://doi.org/10.5194/acp-16-15371-2016, 2016.

Matthias, V., Dörnbrack, A., and Stober, G.: The extraordinarily strong and cold polar vortex in the early northern winter 2015/2016, Geophys. Res. Lett., 43, 12287-12294, https://doi.org/10.1002/2016GL071676, 2016.

Montzka, S. A., Butler, J. H., Elkins, J. W., Thompson, T. M., Clarke, A. D., and Lock, L. T.: Present and future trends in the atmospheric burden of ozone-depleting halogens, Nature, 398, 690-694, 1999.

Müller, R., Grooß, J.-U., Lemmen, C., Heinze, D., Dameris, M., and Bodeker, G.: Simple measures of ozone depletion in the polar stratosphere, Atmos. Chem. Phys., 8, 251-264, https://doi.org/10.5194/acp-8-251-2008, 2008.

Pitts, M. C., Thomason, L. W., Poole, L. R., and Winker, D. M.: Characterization of Polar Stratospheric Clouds with spaceborne lidar: CALIPSO and the 2006 Antarctic season, Atmos. Chem. Phys., 7, 5207-5228, https://doi.org/10.5194/acp-7-5207-2007, 2007.

Pitts, M. C., Poole, L. R., and Gonzalez, R.: Polar stratospheric cloud climatology based on CALIPSO spaceborne lidar measurements from 2006 to 2017, Atmos. Chem. Phys., 18, 1088110913, https://doi.org/10.5194/acp-18-10881-2018, 2018.

Pommereau, J.-P., Goutail, F., Lefèvre, F., Pazmino, A., Adams, C., Dorokhov, V., Eriksen, P., Kivi, R., Stebel, K., Zhao, X., and van Roozendael, M.: Why unprecedented ozone loss in the Arctic in 2011 ? Is it related to climate change?, Atmos. Chem. Phys., 13, 5299-5308, https://doi.org/10.5194/acp-13-5299-2013, 2013.

Prinn, R. G., Weiss, R. F., Fraser, P. J., Simmonds, P. G., Cunnold, D. M., Alyea, F. N., O'Doherty, S., Salameh, P., Miller, B. R., Huang, J., Wang, R. H. J., Hartley, D. E., Harth, C., Steele, L. P., Sturrock, G., Midgley, P. M., and McCulloch, A.: A history of chemically and radiatively important gases in air de- duced from ALE/GAGE/AGAGE, J. Geophys. Res., 105, 1775117792, 2000.

Randel, W., Wu, F., Oltmans, S., Rosenlof, K., and Nedoluha, G.: Interannual changes in stratospheric water vapor and correlations with tropical tropopause temperatures, J. Atmos. Sci., 61, 2133 2148, 2004.

Revell, L. E., Bodeker, G. E., Huck, P. E., Williamson, B. E., and Rozanov, E.: The sensitivity of stratospheric ozone changes through the 21st century to $\mathrm{N}_{2} \mathrm{O}$ and $\mathrm{CH}_{4}$, Atmos. Chem. Phys., 12, 11309-11317, https://doi.org/10.5194/acp-12-113092012, 2012.

Revell, L. E., Stenke, A., Rozanov, E., Ball, W., Lossow, S., and Peter, T.: The role of methane in projections of 21 st century stratospheric water vapour, Atmos. Chem. Phys., 16, 13067-13080, https://doi.org/10.5194/acp-16-13067-2016, 2016.

Rex, M., von der Gathen, P., Braathen, G. O., Harris, N. R. P., Reimer, E., Beck, A., Alfier, R., Krüuger-Carstensen, R., Chipperfield, M., De Backer, H., Balis, D., O'Connor, F., Dier, H., Dorokhov, V., Fast, H., Gamma, A., Gil, M., Kyrö, E., Litynska, Z., Mikkelsen, I. S., Molyneux, M., Murphy, G., Reid, S. J., Rummukainen, M., and Zerefos, D.: Chemical ozone loss in the Arctic winter 1994/1995 as determined by the Match technique, J. Atmos. Chem., 32, 35-59, 1999.

Rex, M., Salawitch, R. J., von der Gathen, P., Harris, N. R. P., Chipperfield, M., and Naujokat, B.: Arctic ozone loss and climate change, Geophys. Res. Lett., 31, L04116, https://doi.org/10.1029/2003GL018844, 2004.

Rex, M., Salawitch, R. J., Deckelmann, H., von der Gathen, P., Harris, N. R. P., Chipperfield, M. P., Naujokat, B., Reimer, E., Allaart, M., Andersen, S. B., Bevilacqua, R., Braathen, G. O., Claude, H., Davies, J., De Backer, H., Dier, H., Dorokhov, V., Fast, H., Gerding, M., Godin-Beekmann, S., Hoppel, K., Johnson, B., Kyrö, E., Litynska, Z., Moore, D., Nakane, H., Parrondo, M. C., Risley, A. D., Skrivankova, P., Stübi, R., Viatte, P., Yushkov, V., and Zerefos, C.: Arctic winter 2005: Implications for stratospheric ozone loss and climate change, Geophys. Res. Lett., 33, L23808, https://doi.org/10.1029/2006GL026731, 2006.

Riese, M., Ploeger, F., Rap, A., Vogel, B., Konopka, P., Dameris, M., and Forster, P.: Impact of uncertainties in atmospheric mixing on simulated UTLS composition and related radiative effects, J. Geophys. Res., 117, D16305, https://doi.org/10.1029/2012JD017751, 2012.

Rosenfield, J. E., Douglass, A. R., and Considine, D. B.: The impact of increasing carbon dioxide on ozone recovery, J. Geophys Res., 107, 4049, https://doi.org/10.1029/2001JD000824, 2002.

Sagi, K., Pérot, K., Murtagh, D., and Orsolini, Y.: Two mechanisms of stratospheric ozone loss in the Northern Hemisphere, studied using data assimilation of Odin/SMR atmospheric observations, Atmos. Chem. Phys., 17, 1791-1803, https://doi.org/10.5194/acp-17-1791-2017, 2017.

Salmi, S.-M., Verronen, P. T., Thölix, L., Kyrölä, E., Backman, L., Karpechko, A. Yu., and Seppälä, A.: Mesosphere-to-stratosphere descent of odd nitrogen in February-March 2009 after sudden stratospheric warming, Atmos. Chem. Phys., 11, 4645-4655, https://doi.org/10.5194/acp-11-4645-2011, 2011.

Sander, S. P., Abbatt, J., Barker, J. R., Burkholder, J. B., Friedl, R. R., Golden, D. M., Huie, R. E., Kolb, C. E., Kurylo, M. J., Moortgat, G. K., Orkin, V. L., and Wine, P. H.: Chemical Ki- 
netics and Photochemical Data for Use in Atmospheric Studies, Evaluation No. 17, JPL Publication 10-6, Jet Propulsion Laboratory, Pasadena, USA, 2011.

Schoeberl, M. R., Dessler, A. E., and Wang, T.: Simulation of stratospheric water vapor and trends using three reanalyses, Atmos. Chem. Phys., 12, 6475-6487, https://doi.org/10.5194/acp12-6475-2012, 2012.

Sinnhuber, B.-M., Stiller, G., Ruhnke, R., von Clarmann, T., Kellmann, S., and Aschmann, J.: Arctic winter 2010/2011 at the brink of an ozone hole, Geophys. Res. Lett., 38, L24814, https://doi.org/10.1029/2011GL049784, 2011.

Smalley, K. M., Dessler, A. E., Bekki, S., Deushi, M., Marchand, M., Morgenstern, O., Plummer, D. A., Shibata, K., Yamashita, Y., and Zeng, G.: Contribution of different processes to changes in tropical lower-stratospheric water vapor in chemistry-climate models, Atmos. Chem. Phys., 17, 8031-8044, https://doi.org/10.5194/acp-17-8031-2017, 2017.

Solomon, S., Garcia, R. R., Rowland, F. S., and Wuebbles, D. J.: On the depletion of Antarctic ozone, Nature, 321, 755-758, 1986.

Solomon, S., Ivy, D. J., Kinnison, D., Mills, M. J., Neely, R. R., and Schmidt, A.: Emergence of healing in the Antarctic ozone layer, Science, 353, 269-274, https://doi.org/10.1126/science.aae0061, 2016.

Spang, R., Hoffmann, L., Müller, R., Grooß, J.-U., Tritscher, I., Hüopfner, M., Pitts, M., Orr, A., and Riese, M.: A climatology of polar stratospheric cloud composition between 2002 and 2012 based on MIPAS/Envisat observations, Atmos. Chem. Phys., 18, 5089-5113, https://doi.org/10.5194/acp-18-5089-2018, 2018.

Stamnes, K., Tsay, S.-C., Wiscombe, W., and Jayaweera, K.: Numerically stable algorithm for discrete-ordinate-method radiative transfer in multiple scattering and emitting layered media, Appl. Opt., 27, 2502-2509, 1988.

Stenke, A. and Grewe, V.: Simulation of stratospheric water vapor trends: impact on stratospheric ozone chemistry, Atmos. Chem. Phys., 5, 1257-1272, https://doi.org/10.5194/acp-5-1257-2005, 2005.
Strahan, S. E. and Douglass, A. R.: Decline in Antarctic ozone depletion and lower stratospheric chlorine determined from Aura Microwave Limb Sounder observations, Geophys. Res. Lett., 45, 382-390. https://doi.org/10.1002/2017GL074830, 2018.

Streibel, M., Rex, M., von der Gathen, P., Lehmann, R., Harris, N. R. P., Braathen, G. O., Reimer, E., Deckelmann, H., Chipperfield, M., Millard, G., Allaart, M., Andersen, S. B., Claude, H., Davies, J., De Backer, H., Dier, H., Dorokov, V., Fast, H., Gerding, M., Kyrö, E., Litynska, Z., Moore, D., Moran, E., Nagai, T., Nakane, H., Parrondo, C., Skrivankova, P., Stübi, R., Vaughan, G., Viatte, P., and Yushkov, V.: Chemical ozone loss in the Arctic winter 2002/2003 determined with Match, Atmos. Chem. Phys., 6, 2783-2792, https://doi.org/10.5194/acp-6-2783-2006, 2006.

Thölix, L., Backman, L., and Ojanen, S.-M.: The effects of driver data on the performance of the FinROSE chemistry transport model, Int. J. Remote Sens., 31, 6401-6408, 2010.

Thölix, L., Backman, L., Kivi, R., and Karpechko, A. Yu.: Variability of water vapour in the Arctic stratosphere, Atmos. Chem. Phys., 16, 4307-4321, https://doi.org/10.5194/acp-164307-2016, 2016.

Tian, W. S., Chipperfield, M. P., and Lü, D. R.: Impact of increasing stratospheric water vapor on ozone depletion and temperature change, Adv. Atmos. Sci., 26, 423-437, https://doi.org/10.1007/s00376-009-0423-3, 2009.

Vogel, B., Feck, T., and Grooß, J. U.: Impact of stratospheric water vapor enhancements caused by $\mathrm{CH}_{4}$ and $\mathrm{H}_{2} \mathrm{O}$ increase on polar ozone loss, J. Geophys. Res., 116, D05301, https://doi.org/10.1029/2010JD014234, 2011.

Wohltmann, I., Wegner, T., Müller, R., Lehmann, R., Rex, M., Manney, G. L., Santee, M. L., Bernath, P., Sumińska-Ebersoldt, O., Stroh, F., von Hobe, M., Volk, C. M., Hösen, E., Ravegnani, F., Ulanovsky, A., and Yushkov, V.: Uncertainties in modelling heterogeneous chemistry and Arctic ozone depletion in the winter 2009/2010, Atmos. Chem. Phys., 13, 3909-3929, https://doi.org/10.5194/acp-13-3909-2013, 2013. 